\author{
SERIES "CONTRIBUTIONS FROM THE EUROPEAN RESPIRATORY MONOGRAPHS" \\ Edited by M. Decramer and A. Rossi \\ Number 1 in this Series
}

\title{
Allergy markers in respiratory epidemiology
}

\author{
S. Baldacci*, E. Omenaas", M.P. Oryszczyn
}

\begin{abstract}
Allergy markers in respiratory epidemiology. S. Baldacci. (C)ERS Journals Ltd 2001. ABSTRACT: Assessing allergy by measurement of serum immunoglobulin (Ig) $E$ antibodies is fast and safe to perform. Serum antibodies can preferably be assessed in patients with dermatitis and in those who regularly use antihistamines and other pharmacological agents that reduce skin sensitivity.

Skin tests represent the easiest tool to obtain quick and reliable information for the diagnosis of respiratory allergic diseases. It is the technique more widely used, specific and reasonably sensitive for most applications as a marker of atopy.

Measurement of serum IgE antibodies and skin-prick testing may give complimentary information and can be applied in clinical and epidemiological settings.

Peripheral blood eosinophilia is less used, but is important in clinical practice to demonstrate the allergic aetiology of disease, to monitor its clinical course and to address the choice of therapy. In epidemiology, hypereosinophilia seems to reflect an inflammatory reaction in the airways, which may be linked to obstructive airflow limitation.
\end{abstract}

Eur Respir J 2001; 17: 773-790.

*Institute of Clinical Physiology, Pisa, Italy. "Dept of Thoracic Medicine, University of Bergen, Bergen, Norway. INSERM U472, Villejuif, France.

Correspondence: S. Baldacci, Istituto di Fisiologia Clinica, CNR, Via Trieste 41, 56126 Pisa, Italy. Fax: 3950503596

Keywords: Atopy, eosinophilia, epidemiology, general population, immunoglobulin E, skin test reactivity

Received: December 112000

Accepted after revision December 15 2000

The term "allergy" was introduced in 1906 by the Viennese paediatrician von Pirquet to point out a condition of altered reactivity in a host organism. He observed that the introduction of an external substance in a tissue could alter the tissue reactivity upon a subsequent contact with the same substance. Previously, the term "allergy" was used to define these altered responses, either protective or harmful. More recently, this term has been used to indicate an abnormal modality (hypersensitivity) of the organism to respond to antigenic stimuli (antigens) which are inactive in normal subjects [1].

In 1921, the experiments of two German physicians, C. Prausnitz and H. Küstner, demonstrated that allergy was correlated with a serum factor which was subsequently defined "reagine" [2]. In 1923 A.F. Coca and R. Cooke introduced the term "atopy" to define a constitutional status of predisposition to develop allergic diseases as pollinosis and bronchial asthma with a "reaginic" pathogenesis [3]. The term atopy, of Greek etymology, indicates clinical conditions with unusual characteristics.

For many years, few investigators tried to identify and to separate the reagines. Only in 1966-1967, in Denver, USA, two researches were able to separate, in the serum of atopic subjects, a factor with high reaginic activity, pointing out that it did not identify itself with any immunoglobulin (Ig) class known at the time. This new Ig was called "IgE" [4].

At the same time, in Sweden, two other researchers, H. Bennich and S.G.O. Johansson, identified a new Ig in a patient with a myeloma, which was defined IgND. Furthermore, they observed that high levels of IgND were present in the serum of atopic subjects [4]. The immunological and physical-chemical characterization allowed the identification of the IgND with the IgE. In 1968 in Losanna, an International Committee of experts of the World Health Organization International Reference Centre for Immunoglobulins decided to call this immunoglobulin definitively "IgE" recognizing it as the 5 th antibody class.

The discovery of $\operatorname{IgE}$ has led to an understanding of the mechanisms of allergy. It has also led to the development of diagnostic tools as well as analyses and standardization of allergen extracts. It is possible to measure not only the pure protein content, but also the allergenicity in terms of the antigen that reacts with the $\operatorname{IgE}$ antibodies. The next possibility is to develop allergens for diagnostic and therapeutic endpoints including immunotherapy [5]. Advanced treatment principles of immunological modification of the functions of $\operatorname{IgE}$ antibodies and the mechanisms that regulate the IgE production may in the future include blocking or down regulation of $\mathrm{IgE}$ in patients with allergic rhinitis and asthma [5].

Atopy, with or without clinical symptoms, is an important risk factor for asthma [6], hay fever and eczema and creates interest for assessment in epidemiological studies. Clinicians tend to validate IgE antibody testing against its prediction of clinical atopic disease, while epidemiologists want to identify individuals with atopy regardless of the presence of disease. Thus criteria for test positivity in clinical and epidemiological settings may differ.

In epidemiological surveys, application of biological markers is ideally required to assess the exposuredisease relationship [7]. However, allergic sensitization, assessed as serum specific $\operatorname{IgE}$ antibodies, is not an 
indicator of allergen exposure alone. In addition to allergen exposure, serum specific IgE antibodies reflect the individual's susceptibility for allergic sensitization as well as health effects, and may reflect more of the events in the airways when compared to skin tests thus giving additional information [8].

Skin tests represent a practicable and reproducible investigation which allows, when correctly performed, quicker and cheaper results than any other technique in the diagnosis of respiratory allergic diseases.

Skin tests give a semiquantitative measure of sensitization, as they are supposed to reflect the sensitization status of airways mucosae. In fact, using a skin test, an interaction is artificially created between $\operatorname{IgE}$ bound to mast cells receptors and the same allergens which are present in the atmosphere and which are spontaneously inhaled.

It is important to point out that there has been wide use of skin test reactivity in respiratory epidemiological studies on general population samples, over recent years, to improve the knowledge on the natural history of airways obstructive diseases. In fact, atopy, as assessed by skin test reactivity, is considered a risk factor for asthma and for bronchial hyperresponsiveness, which is considered the main functional characteristic of asthma [9]. However, atopic predisposition, as assessed by prick test reactions, seems to be related not only to classical allergic conditions and symptoms, but also to other respiratory problems.

In contrast to the "British hypothesis" [10], but in agreement with the "Dutch hypothesis" [10], Finnish studies showed that atopy predispose to chronic bronchitis and, furthermore, atopy and smoking seemed to have an independent and additive effect on both the prevalence and incidence of chronic bronchitis [10].

During the past $20 \mathrm{yrs}$, there has been a growing interest in the effector functions of the eosinophil granulocyte, including a variety of clinical conditions associated with hypereosinophilia, such as asthma, allergic diseases, intestinal diseases, joint diseases and skin diseases [11].

Studies of allergy and respiratory disease have traditionally used allergy skin test reactivity, serum IgE levels or peripheral blood eosinophilia to identify atopic subjects. The strong correlation between these phenotypic markers has led to the common assumption that they are more or less interchangeable indicators of the atopic state. However, recent epidemiological investigations have provided evidence that each of these markers may represent a specific risk factor for specific categories of atopic diseases [12]. In particular, peripheral blood eosinophilia has been identified as an independent inflammatory marker for symptoms of cough and phlegm, distinct from IgE or skin test reactivity [12].

Furthermore, increased serum total $\operatorname{IgE}$ levels and peripheral blood eosinophil counts are neither closely related nor exclusively present in atopic individuals. Serum total IgE levels are increased in nonatopic smokers and peripheral blood eosinophils are also elevated in parasitic infections and in certain neoplasms [13].

In the development of allergic diseases, an important role is played by the environmental allergens, which stimulate an immunological specific IgE response in genetically predisposed subjects. The reacting substances, which are immunologically true antigens, are generally called allergens [2]. They are heterologous proteins or glycoproteins inducing specific allergic reactions in sensitized subjects. Allergens causing atopic reactions are able to induce IgE production and, by interacting with them, to determine clinically evident manifestations. Allergens are classified according to the way of penetration into the organism: by inhalation (aeroallergens), by ingestion, by injection or by contact.

The aim of this review article is to summarize the epidemiological evidence which has emerged during the last decades relating the role of allergic markers such as serum total and specific IgE, skin reactivity and eosinophils in respiratory epidemiology.

\section{Total and specific immunoglobulin $\mathbf{E}$ antibodies}

\section{Clinical and epidemiological importance}

Assessment of IgE antibodies is usually performed in order to evaluate atopy. Subjects who are readily triggered to produce IgE antibodies after exposure to common environmental allergens are defined as atopic [14]. This definition excludes those who have high total IgE levels, but no specific IgE antibodies against common environmental allergen, as measured by skin-prick testing or serum specific IgE antibodies. It also excludes those who have become sensitized only to uncommon allergens [15].

The role $\mathrm{IgE}$ plays in immediate-hypersensitivity (allergic) reactions is well understood. Consequently, nowadays $\mathrm{IgE}$ measurements in serum are performed more frequently as part of routine allergy testing. They are easy to perform, and new methods and equipment make them less expensive to use. Furthermore, external quality assurance schemes are routinely used and results of testing are likely to be identical irrespective of where they have been performed. Use of long-acting antihistamines will not affect the results of serum examinations, while it can reduce skin tests. The relationship between the clinical history and IgE antibody testing is not always quantitative in the clinical setting. Likewise, not all symptoms associated with allergic disease are directly related to IgE-mediated hypersensitivity reactions, for example intrinsic asthma, drug and food intolerance. Consequently, it is advisable to ensure that symptoms are genuinely provoked by an allergic mechanism before undertaking allergy treatment, which will be time consuming, expensive and demanding good collaboration between patient and doctor.

The large range of normal adult IgE levels results in a considerable overlapping of normal and atopic ranges and, consequently, the test cannot identify the atopic person. In a recent published textbook [8] circulating levels $<20 \mathrm{kU} \cdot \mathrm{L}^{-1}$ render a diagnosis of atopy unlikely, while concentrations $>180 \mathrm{kU} \cdot \mathrm{L}^{-1}$ indicate a likely diagnosis of atopy. However, there is significant variation by sex, age, smoking habits and geography which may indicate that local reference values with proper adjustments should be applied [16]. Furthermore, 
markedly raised IgE levels have been reported in a variety of other conditions, including parasitic disease, Wiskott-Aldrich syndrome, Job-Buckley syndrome, alcoholism, human immune deficiency virus (HIV) syndrome, pemphigoid and occasionally, Hodgkin's disease as well as after severe burns [8]. As a rule, total IgE levels among atopics correlate with the size of the target organ, so the lowest levels are observed among rhinitics, the highest in those with atopic eczema, and the intermediate in asthmatics [8].

An elevated total IgE is more likely to be correlated with multiple positive specific IgE (RAST) tests than is a normal total $\mathrm{IgE}[8,17]$. Levels $>5,000 \mathrm{kU} \cdot \mathrm{L}^{-1}$, which often occur in cases with severe atopic eczema, are a warning that artefactually high results may have occurred in the IgE antibody test. Although a total IgE estimation is not a good diagnostic test to differentiate atopy from normal, when taken together with the clinical history it allows a more complete interpretation of the available data.

The routine use of $\operatorname{IgE}$ antibody tests should be restricted to diseases in which the role of IgE has been well documented, such as allergic rhinitis, bronchial asthma, atopic eczema, food, venom- and drug-induced anaphylaxis and bronchopulmonary aspergillosis [8].

Normal values of $\operatorname{IgE}$ are usually very low, but people with hereditary or constitutional predisposition to allergy (atopy) produce relatively greater quantities of $\mathrm{IgE}$. In addition, the production of $\mathrm{IgE}$ antibodies can continue for years after a contact with an allergen. High levels of total serum IgE in humans have been associated with wheeze, hay fever, asthma and eczema.

An increasing array of blood tests is available to measure specific IgE in serum directly. A positive skin test relies on both presence of specific allergic reactions as well as unspecific reactions in the skin, which can promote degranulation of sensitized mast cells. The lack of agreement between skin and serological tests may reflect differences in the presentation of allergen and/or the presence of non-IgE mediated skin reactions.

\section{Prevalence in epidemiological studies}

Observed variation in the prevalence of atopy and atopic disease may reflect a true variation. However, this may partly be explained by variation in the prevalence of the recognized risk factors, which should always be taken into account.

There is some knowledge of total serum IgE levels in selected and general populations, while little information is available on prevalences of serum specific IgE antibodies due to higher costs of the examination than for skin testing. Total $\operatorname{IgE}$ in a population is normally distributed after logarithmic transformation, with a relatively small proportion of individuals having levels of total IgE below the limits of detection of the test $\left(2 \mathrm{kU} \cdot \mathrm{L}^{-1}\right)$. The geometric mean of total serum $\mathrm{IgE}$ as well as specific serum IgE was lower in Nordic populations $[17,18]$ than in young adults in South Wales [19], adults in Tucson, Arizona [20], in Italy [21] and in the Netherlands [22]. This may partly be due to differences in methods, in mean age of the populations, as well as differences in allergen exposure. In the

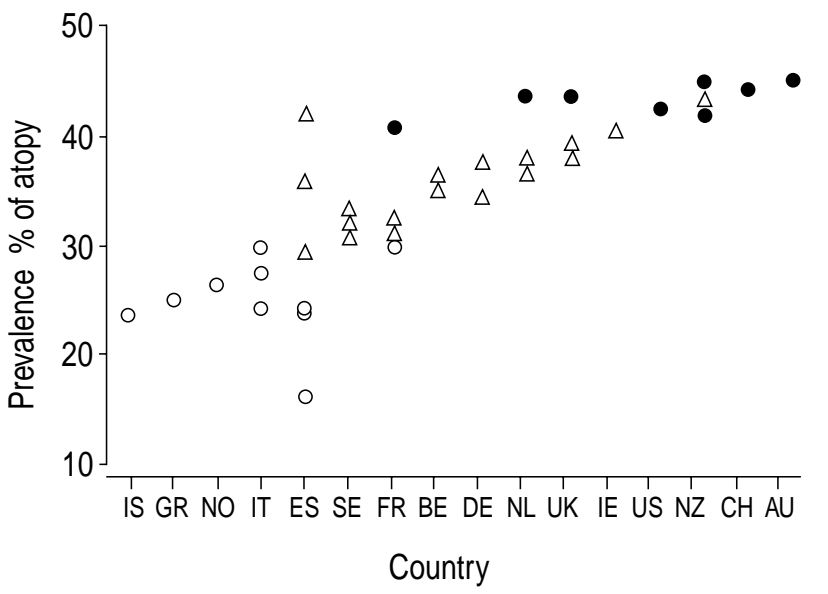

Fig. 1. - Prevalence of atopy in young adults, defined as specific immunoglobulin (Ig)E to any of the five allergens tested in each centre plotted by country and centre in the European Community Respiratory Health Survey. Each symbol represents the value for one centre. The countries are ordered along the $\mathrm{X}$-axis. Values significantly above or below the median for 35 centres are indicated. The countries are: IS: Iceland; GR: Greece; NO: Norway; IT: Italy; ES: Spain; SE: Sweden; FR: France; BE: Belgium; DE: Germany; NL: Netherlands; UK: United Kingdom; IE: Ireland; US: United States; NZ: New Zealand; CH: Switzerland; AU: Australia. Adapted from reference [16]. $\bigcirc: 95 \%$ confidence interval (CI) below and excludes study median; $\triangle: 95 \% \mathrm{CI}$ includes study median; : 95\% CI above and excludes study median.

European Community Respiratory Health Survey (ECRHS) [16], the prevalence of atopy, assessed as serum specific IgE antibodies, was lowest in young adults in the Nordic countries and highest in those living in the UK, New Zealand and Australia (fig. 1) [16]. Thus, serum specific IgE levels vary with area of residence possibly reflecting differences in allergen exposure and in individual susceptibility. There have been few studies documenting any change in the prevalence of atopy assessed with specific IgE antibodies within populations. Two small studies have reported an increase of atopy in children [23, 24].

A positive relationship has been reported between total serum $\operatorname{IgE}$ level and presence of serum specific IgE antibodies in clinical settings, in selected populations as well as in a general population [17]. The predictive value of having one or more serum specific IgE antibodies given total serum IgE level in the highest quintile is nearly doubled in males compared to females, in younger compared to older subjects and in nonsmokers compared to smokers [17]. However, this was not observed in young adults in the ECRHS [16].

\section{Allergy and skin test reactivity}

\section{Clinical and epidemiological importance}

An accurate diagnosis of allergy precedes the effective management. Allergy tests are used to define the subset of subjects who, because of sensitivity to allergens, have symptoms caused by one or more allergens, and to identify the involved allergen or allergens.

Specific sensitization assessment should always be performed before allergen eradication procedures, in 
order to implement an appropriate therapy for any particular individual [25]. On the contrary, negative results of allergy tests can discriminate subjects whose symptoms are not caused by allergens from subjects with allergen-mediated disease. Skin tests are in vivo allergy tests used to detect immediate (antibodymediated) or delayed (cell-mediated) sensitivity. They were first used over a century ago to confirm the association between hay fever and pollen sensitivity [2]. The delayed cutaneous response is defined as the skin erythema and induration produced by an intradermal test $6 \mathrm{~h}$ after applying the test.

Skin-prick testing represents an inexpensive, quick, safe diagnostic procedure for allergy, but, in order to obtain reliable clinical results, a few rules must be followed. The allergen potency must be kept constant by use of freeze-dried extracts, stored at $\leqslant-10^{\circ} \mathrm{C}[26]$. Dilutions of the concentrated extract must be accurately prepared. Considering prick tests, $50 \%$ glycerine is used to preserve dilutions, while intradermal test extracts are diluted in HSA-saline (normal saline with $0.03 \%$ human serum albumin preserved with $0.4 \%$ phenol).

Patients must avoid drugs that inhibit the immediate cutaneous response such as astamizole for $\geqslant 6$ weeks; hydroxyzine, ketotifen, and tricyclic antidepressants, like imipramine, for $\geqslant 2$ weeks; conventional antihistamines and oral or injected adrenergics for $\geqslant 72 \mathrm{~h}$ [26]. In addition, test results may be misleading in skin disorders such as dermatographism and generalized eczema. It is better to do skin tests at the same time of the day to minimize circadian effects on the response.

The number of allergens used in clinical practice has been increasing and includes extracts derived from many pollens and moulds, various dusts and insects, animal pelts, foodstuffs and numerous bacterial vaccines. In recent decades, a patient having an allergy evaluation might be theoretically tested for as many as 300 allergenic substances.

Skin-prick tests have been commonly chosen to measure atopy in populations, largely because the procedure is simple and well documented. However, the criteria by which atopy is defined are not well established: the minimum skin weal size used to indi- cate atopy remains controversial and the number of allergens required to detect all atopic subjects is unknown [27]. Indeed, because of the wide number of potentially allergenic substances and variations in local allergen levels, the number of allergens in a screening panel could be very large, although in a few countries, such as in the UK and in Sweden, minipanels of four selected allergens detect most atopy [27]. Finally, although skin-prick tests have been shown to correlate well with specific serum $\operatorname{IgE}$, recent data indicate that the presence of skin-prick test reactivity does not have the same meaning as increased level of total serum IgE; thus, in epidemiological studies, it is advisable to use both allergy markers, in order to have a complete and precise evaluation of the immunological status [12].

\section{Prevalence in epidemiological studies}

In the last 15 years, two Italian general population samples, selected according to standardized and adequately defined procedures, were investigated and followed over time [28]. They live in two different areas, a rural area in Northern Italy (Po river Delta) and an urban area in Central Italy (Pisa). The prevalence of respiratory symptoms was higher in the urban area compared with the rural area. Conversely, no difference between the rural and urban areas was evident when comparing skin reactivity prevalence as a marker of atopy: $31 \%$ in the rural area compared to $32 \%$ in the urban area $[9,28]$.

Table 1 shows the prevalence of skin test reactivity in different studies and populations: random samples of communities, subjects free of allergic symptoms or allergic populations. A wide range of prevalence rates of skin-prick reactivity $(21-49 \%)$ has been reported from studies on general populations or subjects free of allergic symptoms. Studies on allergic populations have reported prevalences $>50 \%$.

Possible causes of this large variability reported in the literature, include the characteristics of the populations observed, the number and the potency of allergenic extracts, and the criteria for evaluating of skin reaction.

Table 1. - Prevalence of skin test reactivity in different epidemiological studies

\begin{tabular}{|c|c|c|c|}
\hline Author & [Ref.] & Population & $\begin{array}{l}\text { Prevalence of } \\
\text { skin reactivity \% }\end{array}$ \\
\hline \multicolumn{4}{|c|}{ Children - Adolescents } \\
\hline HAAHTELA & [29] & 708 Finnish, 15-17 yrs & 49 \\
\hline \multicolumn{4}{|l|}{ Adults } \\
\hline BARBEE & [30] & US community sample of 3012 subjects, $3-75+$ yrs & 34 \\
\hline BALDACCI & [28] & 2,184 subjects participating in the Pisa survey, $8-84 \mathrm{yrs}$ & 32 \\
\hline BALDACCI & [9] & 2,632 subjects participating in the Po Delta survey, $8-75 \mathrm{yrs}$ & 31 \\
\hline TOLlerud & [12] & $\begin{array}{l}1,071 \text { males participating in the Normative Aging Study, } \\
21-80 \text { yrs }\end{array}$ & 21 \\
\hline SIN & [31] & 277 young healthy individuals in Izmir, Turkey, $15-25$ yrs & 46 \\
\hline NowAK & [32] & $\begin{array}{l}1,890 \text { subjects participating in the ECRHS survey, } \\
\text { in West and East Germany, } 20-44 \text { yrs }\end{array}$ & $\begin{array}{l}\text { East } 30 \\
\text { West } 36\end{array}$ \\
\hline HERXHEIMER & [33] & 300 subjects with respiratory allergies in London, $5-75 \mathrm{yrs}$ & 95 \\
\hline FREIDHOFF & $34]$ & 262 subjects reporting allergies in Baltimore, $18-55$ yrs & 55 \\
\hline SIBBALD & [35] & 1,305 rhinitic subjects in Southwest London, $16-65$ yrs & 59 \\
\hline BOULET & [36] & 3,371 allergic patients in Canada, $\geqslant 16$ yrs & 80 \\
\hline
\end{tabular}


Generally, in epidemiological studies, the choice of representative samples, randomly selected and stratified for sex, age, socioeconomic status or other discriminating factors, allows inference to be made on the general population living in a certain area.

The potency of allergenic extracts is one factor that may account for discrepancies between different studies; nevertheless, the use of new extraction methods in recent epidemiological studies should have reduced these differences.

The most important sources of variability among different epidemiological studies might be different criteria of reading skin reactions, such as different size of reaction or different modalities of reading (maximal with or without minimal diameter, area, etc.). Finally, the use of different allergens (qualitatively or quantitatively) may constitute an additional source of variability [37].

With regard to specific skin responses, epidemiological studies indicate that Dermatophagoides, Parietaria, and Graminaceae are the allergens which most frequently give positive reactions in Italy [9, 38].

In an Australian study [27] the prevalences of sensitization, investigated in three populations of schoolchildren living in different climatic areas, were higher for house dust mites in Belmont and Villawood, and for pollens of plantain, timothy grass, rye grass and Aspergillus fumigatus in Wagga Wagga. The prevalence of animal dander sensitization was low in all areas.

Sin et al. [31] reported that sensitization to house dust mites was most frequent in Turkish subjects aged $15-25$ yrs.

\section{Eosinophils}

\section{Clinical and epidemiological importance}

Eosinophils release specific lipid mediators, including leukotriene $\mathrm{C} 4$, platelet-activating factor (PAF) and lipoxins, and contain four different cationic proteins within their granules: major basic protein (MBP), eosinophil peroxidase (EPO), eosinophil cationic protein (ECP) and eosinophil derived neurotoxin, which are characterized by a strong cytotoxic potential [11].

The eosinophil is derived from the common haematopoietic stem cell. The most important growth factors involved in eosinophil maturation and proliferation are granulocyte-macrophage colony stimulating factor, interleukin-3 and interleukin-5. The normal concentration of eosinophils in the blood is $1-4 \%$ of the leukocytes, while it is as high as 100-300 times in tissues, suggesting that the eosinophil should be mainly regarded as a tissue cell. In the nasal secretion of subjects with rhinitis the eosinophils concentration may also reach very high levels, accounting for $>90 \%$ of all the recovered cells. The half-life of eosinophil in the blood is $4-5 \mathrm{~h}$, while the half-life in tissues is $8-12$ days [39].

In clinical practice, peripheral blood eosinophil counts are widely used to demonstrate the allergic aetiology of disease, to monitor its clinical course and to address the choice of therapy [40]. Moreover, this parameter seems to be an early atopy marker since elevated eosinophil count in peripheral blood of apparently healthy infants at 3 months of age is associated with a subsequent diagnosis of atopic disease [41].

The diagnosis of atopic disease is often difficult in small children because of differences in symptoms and lack of specific and reliable laboratory tests. A study, evaluating the significance of four commonly used laboratory tests (blood eosinophil counts, total serum $\mathrm{IgE}$ and eosinophil and mast cells in the nasal smear) as atopy markers in 178 children aged $3 \mathrm{yr}$, showed that a blood eosinophil count $>600 \times 10^{3} \cdot \mu \mathrm{L}^{-1}$, as well as an increased number of eosinophil and mast cells in the nasal smear, were associated with atopy. However, normal levels of these parameters did not exclude atopic disease. Thus, each of these tests had high specificity, but low sensitivity [42].

Antigens (via antigen presenting cells) can activate T-helper cells, and subsequent lymphokine production. Some of these lymphokines (interleukin-4, interleukin-5 and interferon gamma) can activate B lymphocytes, which are in turn responsible for IgE secretion. Moreover, T-helper cells-derived lymphokines are also known to be associated with higher eosinophil counts. As a consequence, allergens can trigger both $\mathrm{IgE}$ synthesis and eosinophil proliferation. However, not only allergic stimuli, but also nonallergic stimuli (especially cigarette smoking) are known to be associated with higher eosinophil counts, possibly via T-cells. Eosinophil proliferation might, therefore, be the result of either allergic and/or nonallergic stimulation [40].

Atopy might be one of the pathophysiological mechanisms responsible for the development and evolution of COPD. Both host and environmental factors, which play an essential role in determining atopy, may influence the risk for the development and evolution of COPD. Atopy may induce or contribute to the development and progress of COPD in many ways, including nonallergic mechanisms. Epidemiological findings have shown that blood eosinophil count appears inversely related to the level of pulmonary function and directly related to the rate of decline of pulmonary function among nonsmokers [43, 44]. In particular, a link of either inflammation (hypereosinophilia alone) or allergic inflammation (eosinophilia in combination with skin test reactivity) with level of forced expiratory volume in one second (FEV1), independent of the effect of cigarette smoking, was found [44]. Furthermore, elevated blood eosinophilia has been found significantly related to several respiratory symptoms and disease diagnoses $[12,45]$. Therefore, on the epidemiological side, peripheral blood eosinophil count can be useful both to investigate the association of host factors and environmental determinants to indicators of allergy prevalence and to evaluate whether allergy is a risk factor with a possibly substantial contribution to the development and progress of either reversible and irreversible airflow obstruction.

\section{Prevalence in epidemiological studies}

The use of different measures of atopy in different studies has complicated the comparison of the results. 
In particular, as regards peripheral blood eosinophils, there are only few epidemiological studies including this atopy marker on a large scale, and, to add further complexity, eosinophil count could be considered both as a continuous and/or as a categorical dichotomous variable.

Mensinga et al. [44] found a prevalence rate of eosinophilia (i.e. $\geqslant 275$ eosinophils $\cdot \mathrm{mm}^{-3}$ ) of $12.9 \%(14$ in males, $11.7 \%$ in females) in the general population sample of Vlagtwedde-Vlaardingen investigated in the initial and in the first follow-up surveys. Further, the analyses made using the data from the subsequent follow-up surveys of the same longitudinal population study, showed prevalence rates of peripheral blood eosinophilia slightly higher $(15.3 \%)$, comprised between the prevalence of skin test positivity $(14.7 \%)$ and of increased serum total IgE level $(16.9 \%)$. The overlap among the three measures was small [13].

In the Normative Aging Study [12], which has analysed the relationship of respiratory symptoms with the three main phenotypic markers (skin test reactivity, serum Ige, peripheral eosinophils), the mean values of eosinophils have been reported both as cells $\cdot \mathrm{mm}^{-3}$ (207 \pm 5 in nonsmokers, $268 \pm 15$ in current smokers) and as percentage on total white blood cells $(3.7 \pm 0.1$ in nonsmokers, $3.9 \pm 0.2 \%$ in current smokers).

Conversely, TAYLOR et al. [46], in a study concerning the association between smoking itself and indicators of allergy, reported lower values of the percentage of eosinophils, $1.67 \%$ in nonsmokers and $1.95 \%$ in smokers.

ULRIK [43], in a study on a population sample of 665 adolescents and young adults, aged 13-23 yrs, reported a prevalence rate of eosinophilia (defined as $>0.25$ cells $\times 10^{3} \cdot \mu \mathrm{L}^{-1}$ ) of $13.2 \%$ in a subgroup of nonsmoking, nonatopic, nonasthmatic subjects with no evidence of bronchial hyperresponsiveness.

In conclusion, these findings support the theory that the role of the eosinophils in obstructive pulmonary diseases extends beyond its role in allergic reactions, suggesting that an increased number of blood eosinophils reflects an inflammatory reaction in the airways, which might cause the development of obstructive airflow limitation.

\section{Modifiers of allergy markers}

Allergy markers are affected by various factors, both endogenous and exogenous, and many pieces of evidence exist nowadays due the conduction of epidemiological studies. Besides well-known factors like smoking [47], additional factors have recently been suggested as potential modifiers of allergy markers but they need to be investigated further. Results are more consistent in the case of total IgE level due to the fact that IgE assessment is largely reliable. In the case of skin prick tests, the lack of standardization on the method of performing the tests has prevented generalization of results. In human beings, eosinophils intervene in atopy and eosinophilia, including circulating eosinophilia, is associated with asthma and with bronchial hyperresponsiveness [48]. Modifiers of eosinophilia have rarely been studied. In order to avoid biases potential modifiers need to be taken into account. Table 2 presents main modifiers of total IgE, SPT and eosinophilia respectively, according to population-based data.

Total immunoglobulin E: relationship to sex, age, ethnic group and environmental factors

Measurements of total $\mathrm{IgE}$ allow some quantitative assessment of genetic phenotype. Total IgE has been linked to chromosome $5 \mathrm{q}$, the site of many interleukines, in pedigrees of parents with asthma [49]. When defining subjects with high total serum $\operatorname{IgE}$ or a positive specific IgE to a common inhalant allergen, linkage to chromosome $11 \mathrm{q}$ has been observed [50], possibly more important when carried by the mother. HANSON et al. [51] showed that twins reared apart had a high concordance of total serum $\operatorname{IgE}$, but not to specific allergens when measured by RAST. These observations suggest that total IgE is largely genetically determined, while sensitization may be largely environmentally determined. As much as $50 \%$ of the variance in total $\mathrm{IgE}$ can be determined by genetic factors $[52,53]$. Also specific IgE may to some degree be under genetic control [54].

Total $\operatorname{IgE}$ are higher in males than in females but this is not always observed at birth [55, 56]. The differences have been shown to be greatest in young adults, although, other studies have observed higher total IgE levels in elderly males compared to females after taking into account age, smoking habit, occupational exposure and presence of respiratory symptoms and disease [17, 57, 58]. The reason for this sex difference has not been satisfactorily explained. One hypothesis could be that a higher proportion of elderly males than elderly females have been more heavily or widely occupationally exposed, while this is not the case in younger age categories, thus representing a cohort effect.

Most reports suggest that males, in adolescence and adulthood, are at an increased risk of sensitization than females, when measured as presence of serum-specific $\mathrm{IgE}$ antibodies or a positive skin test $[17,59,60]$. This sex difference may be limited to some allergens as no significant sex difference for antibodies against birch and timothy was observed in a Norwegian adult population [17].

Total IgE levels depend on age but the exact relationship of dependence is not known [61, 62]. Total $\mathrm{IgE}$ are undetectable at birth except in allergic individuals. Among Greek children aged 1 month-14 yrs, total IgE levels increased by almost $80 \%$ per yr until 5 yrs of age [63]. Among children in the USA, followedup from birth to 4 yrs of age, the major increase was observed before the age of 2 yrs, although total IgE level increased even later [56]. Cross-sectional data suggest that total IgE levels are at their highest in childhood and fall steadily after the age of $15 \mathrm{yrs}$ $[16,21,22,61]$. Longitudinal data from a 20 -yr followup of people living in Tucson, Arizona largely confirm this. There is a rapid decline up to 30 yrs and thereafter the rate of decline gradually slows down [57]. A lack of decline with age, however, has been 
Table 2. - Potential main modifiers of allergy markers according to population-based data

\begin{tabular}{|c|c|c|c|c|}
\hline Factors & $\begin{array}{l}\text { Total } \\
\text { IgE }\end{array}$ & $\begin{array}{c}\text { SPT } \\
\text { Positivity }\end{array}$ & Eosinophils & Comments \\
\hline \multicolumn{5}{|l|}{ Genetics } \\
\hline Genetic markers & + & + & + & Problematic for geneticists \\
\hline Gender & + & + & \pm & $\begin{array}{l}\uparrow \text { IgE for men } \\
\uparrow \text { SPT for men }\end{array}$ \\
\hline Ethnic group & + & + & \pm & $\begin{array}{l}\uparrow \mathrm{IgE} \text { in some groups (genetic, environmental, } \\
\text { social) }\end{array}$ \\
\hline Individual susceptibility & + & + & $?$ & $\uparrow \operatorname{IgE}, \uparrow$ atopy \\
\hline Family history of atopy & + & + & ? & \\
\hline \multicolumn{5}{|l|}{ Individuals } \\
\hline Maternal age at birth & + & ? & ? & $\downarrow \operatorname{IgE}$ in newborns of young mothers \\
\hline Perinatal complications & \pm & ? & ? & IgE in newborns \\
\hline Medication during pregnancy & + & ? & ? & $\uparrow \mathrm{IgE}$ in newborns (progesterone) \\
\hline Head circumference & \pm & $?$ & & $\begin{array}{l}\uparrow \operatorname{IgE} \text { in adults and newborns if head } \\
\text { circumference at birth } \geqslant 37 \mathrm{~cm}\end{array}$ \\
\hline Birth weight & \pm & ? & - & $\downarrow \mathrm{IgE}$ in low birth weight \\
\hline Birth month & + & ? & - & $\uparrow$ IgE during pollen season \\
\hline Age & + & + & + & Increase in youth and decrease with age \\
\hline Infections & \pm & \pm & - & Depend on age of infection \\
\hline Family size & - & + & - & Depends also on birth order \\
\hline \multicolumn{5}{|l|}{ Environmental } \\
\hline Maternal smoking during pregnancy & \pm & ? & ? & Contradictory results for IgE \\
\hline Active smoking & + & $\begin{array}{l}\text { Inversely } \\
\text { related }\end{array}$ & + & $\begin{array}{l}\uparrow \text { IgE with active smoking } \\
\uparrow \text { eosinophils }\end{array}$ \\
\hline Passive smoking & \pm & \pm & \pm & Among children \\
\hline Allergens exposure & + & + & - & \\
\hline Month of test & \pm & ? & - & $\uparrow$ IgE during pollen season \\
\hline Indoor pollution (humidity, mite) & \pm & \pm & ? & $\uparrow$ IgE mites \\
\hline Outdoor pollution $\left(\mathrm{NO}_{2}, \mathrm{SO}_{2}\right.$, diesel $)$ & \pm & \pm & $?$ & $\uparrow$ IgE with diesel \\
\hline Occupational exposure & + & + & $?$ & $\begin{array}{l}\uparrow \text { IgE in individuals exposed to allergens, } \\
\text { dust, gas and fumes }\end{array}$ \\
\hline
\end{tabular}

?: No evidence, investigation is required; \pm : uncertain relationship; +: established relationship; -: not yet studied in populationbased samples; $\uparrow$ : increase; $\downarrow$ : decrease; SPT: skin prick test; $\mathrm{NO}_{2}$ : nitrogen dioxide; IgE: immunoglobulin E.

shown in studies including only males [12, 64], in a nonatopic population [65] and in an adult general population [17]. A lack of fall of the total serum $\operatorname{IgE}$ levels by increasing age in males can be due to a cohort effect, where older males were more frequently exposed to tobacco smoke and occupational exposure than younger males. Furthermore, adjustment for smoking and occupational dust or gas exposure in the statistical analysis may be incomplete.

A cross-sectional survey among Norwegian adults showed a higher prevalence of serum specific IgE in younger than older adults in both males and females. Whether this substantial fall represents a true age effect or if it is a cohort effect is still uncertain and should be addressed in follow-up studies.

Ethnic factors also influence serum total IgE levels since Black and Metis individuals have higher total IgE levels than White individuals [66]. The phenomenon begins at birth [67], probably due to helminthic infestations in such ethnic groups. This has not been confirmed by other studies. More recently, antenatal and perinatal factors have been proposed as potential modifiers of the total IgE response. Head circumference was larger in children with higher levels of cord blood total IgE [68] and serum total IgE [69]. Head circumference has been related to foetal disproportionate growing and so to deregulated immune function responsible for an over production of IgE. Similarly, alcohol and caffeine consumption by the mother during pregnancy were associated with elevated cord blood total IgE level. Such product could modify the immune response of the organisms. Among endogenous factors related to total IgE in females, there is the menstrual cycle with lower values of serum total IgE in the periovulatory phase [70].

Various exogenous factors are likely to affect total IgE level. Total IgE level varies between countries. In the ECRHS [16] the same methods for total serum IgE testing have been performed in multiple centres in Europe, Oceania and North America. Total serum IgE levels (fig. 2) were lowest in young adults in the Nordic countries and highest in southern Europe, Australia and New Zealand [16]. This may be mainly due to environmental, socioeconomic and cultural factors. There is a positive relationship between the cumulative exposure to an allergen and the risk of allergic sensitization [71]. Platts-Mills et al. [72] suggested that there is a level below which sensitization for genetically predisposed individuals is unlikely. At higher levels of exposure, more people will become sensitized [73]. But there is a variation depending on the physical and chemical properties of the allergens. For example, cat allergen is airborne on smaller particles and remains airborne longer [72]. Currently, airborne measurements of exposure are considered too complex for epidemiological studies [72, 74]. 


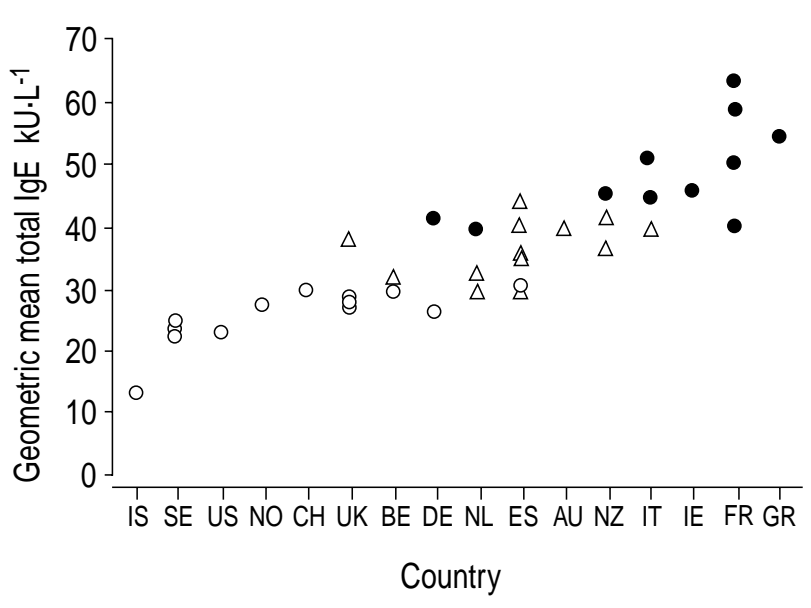

Fig. 2. - Geometric mean total serum $\operatorname{IgE}\left(\mathrm{kU} \cdot \mathrm{L}^{-1}\right)$ in young adults plotted by country and center in the European Respiratory Health Survey. Each symbol represents the value for one center. The countries are ordered along the X-axis. Values significantly above or below the median for 35 centres are indicated. The countries are: IS: Iceland; SE: Sweden; US: United States, NO: Norway; CH: Switzerland; UK: United Kingdom; BE: Belgium; DE: Germany; NL: Netherlands; ES: Spain; AU: Australia; NZ: New Zealand; IT: Italy; IE: Ireland; FR: France; GR Greece. $\bigcirc$ : 95\% confidence interval (CI) below and excludes study median; $\triangle$ : 95\% CI includes study median; $\bigcirc 95 \% \mathrm{CI}$ above and excludes study median. Adapted from ref [16].

Exposure to allergens may not only increase the risk of sensitization, but may also trigger episodes of disease of those sensitized. There is no consistent evidence that exposure to allergen has increased during the last decades [73, 75]. Increases have been observed in two towns in Australia [76]. However, the trend towards better insulated houses with increases in soft furnishing, dampness and reduction in air renewal may influence the level of airborne allergens in the indoor environment [74, 77]. Some studies show increased risk of sensitization of house dust mite allergen and pets [73, 78], while others do not [79].

Month of birth during pollen season may affect cord blood IgE and later in life serum $\operatorname{IgE}[63,80]$. Both outdoor and indoor pollution exposure might be responsible for increased total IgE level. Children living in polluted areas had higher total $\operatorname{IgE}$ level compared to those living in unpolluted areas [81]. Atopy, assessed as skin test positivity, is highest in children who come from small families, with a linear decrease in risk of positivity with increasing number of siblings [82, 83]. On the contrary WJST et al. [84] reported that total IgE levels are higher in children who come from large families, independently of exposure to passive smoking. These observations suggest that some environmental factors associated with large family size protects against the development of atopy and atopic disease. It has been postulated that higher rates of infection in children from large families, and particularly in those with older siblings, may protect them from the subsequent development of atopy by inhibiting the development of Th2-type cells. Furthermore, immunization [85] during childhood and natural infections [86] may have similar effects on the immune system.
Environmental factors such as smoking may modify the gene expression of atopy and atopic disease. The tendency for those with atopic disease to avoid smoking, the "healthy smoker" effect, may raise methodological problems when assessing the relationship between smoking and disease. Cross-sectional studies have shown higher $\operatorname{IgE}$ levels in smokers than in nonsmokers [17, 18, 21, 22, 87]. In a longitudinal study with a 20-yr follow-up [57] smoking was associated with a reduction in the rate at which total $\operatorname{IgE}$ fell with increasing age in people without atopy (skin test positivity) and with an increase in total IgE after middle age in those with atopy. This has, however, not been confirmed with serological measurements excluding bias by skin reactivity changes with age.

Only one report from a nondiseased population has observed a dose-response relationship between smoking and IgE levels [64]. An explanation for higher total serum IgE levels in smokers than nonsmokers may be change in regulatory mechanisms of the $\operatorname{IgE}$ synthesis [88] or increase of specific $\operatorname{IgE}$ related to frequent infestation of their airways [89]. It has been excluded that Th1 in response to bacterial infestations could be responsible for the augmentation of IgE. Th2 cells seem to be involved in the process. There has been no evidence of induction of specific $\operatorname{IgE}$ antibodies against tobacco in smokers.

A higher prevalence of serum specific IgE antibodies against timothy grass and birch in nonsmokers compared to smokers has been observed in a general adult population [17] as for grass and cat allergens in England [62]. One hypothesis often given, is that subjects with allergic symptoms and disease take up smoking less frequently or quit more often than subjects with no allergic symptoms and disease. However, this has never been shown in a prospective study. Another explanation for the lower levels of serum specific IgE antibodies in smokers compared to nonsmokers may be a defective antigenic presentation to immunocompetent cells in the airways [90].

Occupational studies [91, 92] have shown increased rate of sensitization to occupational allergens such as coffee-bean dust, phthaloic anhydride, soyabeans and prawn antigens in those who smoke.

Data existing on this topic are reviewed in table 3. Increased levels of cord IgE in newborns of mothers who smoke have been reported in some [55], but not in all studies [96]. Children from atopic families with one or more smoking parent have higher IgE than those of parents who do not smoke [97]. The relationship between maternal smoking and sensitization still remains unclear as some studies have observed no relationship [98], while others have observed a relationship in male children only [99]. Also in adults passive smoking has been associated with increased total $\operatorname{IgE}$ levels [21].

An exhaustive review of the literature on the effect of parental smoking on atopic status in childhood has been recently proposed [100].

Although total serum IgE levels are stable in adulthood [101] subjects with occupational dust or gas exposure in the general population had a higher total serum IgE level than those not exposed, independent of sex, age and smoking habit $[17,21]$. No relationship between serum specific IgE antibodies and occupational 
Table 3. - Relationship between smoking habits and total immunoglobulin (Ig)E according to recent studies in the general population

\begin{tabular}{|c|c|c|c|c|}
\hline Author & [Ref.] & Subjects & Findings & Comments \\
\hline $\begin{array}{l}\text { BACKER } \\
\text { Denmark, } \\
1992\end{array}$ & [93] & $\begin{array}{l}508 \text { subjects aged } \\
7-16 \text { yrs }\end{array}$ & $\begin{array}{l}\text { No relationship between active } \\
\text { smoking and } \mathrm{IgE} \text { in univariate } \\
\text { analysis }\end{array}$ & $\begin{array}{l}\text { Active smoking increased IgE after } \\
\text { adjustment for age, SPT positivity, } \\
\text { allergic symptoms and family } \\
\text { history of allergic disease }\end{array}$ \\
\hline $\begin{array}{l}\text { JENSEN } \\
\text { Denmark, } \\
1992\end{array}$ & {$[65]$} & $\begin{array}{l}297 \text { smoking volunteers } \\
\text { and } 137 \text { random controls } \\
\text { at follow-up of: } 1 \mathrm{yr} \text {; } \\
\text { mean age: } 44.2 \text { yrs }\end{array}$ & $\begin{array}{l}\text { Higher IgE among smokers than } \\
\text { among nonsmokers in both sexes. } \\
\text { Weighted pack-yr consumption } \\
\text { associated with increased IgE }\end{array}$ & $\begin{array}{l}\text { Quitters had increased IgE levels } \\
\text { during the first } 26 \text { weeks of } \\
\text { abstinence. Return to baseline } \\
\text { after } 1 \text { yr }\end{array}$ \\
\hline $\begin{array}{l}\text { SHERRILL } \\
\text { USA, } \\
1994\end{array}$ & [57] & $\begin{array}{l}\text { General population: } 2,350 \\
\text { subjects seen at least } 1 \\
\text { time during follow-up, } \\
\text { spanning up a period of } \\
20 \text { yrs, aged }>6 \text { yrs at } \\
\text { the first survey (1973) }\end{array}$ & $\begin{array}{l}\text { Higher IgE among smokers than } \\
\text { nonsmokers in both sexes. } \\
\text { Positive association between } \\
\text { pack-yrs and level of IgE, } \\
\text { stronger in male subjects }\end{array}$ & $\begin{array}{l}\text { No significant difference of } \mathrm{IgE} \\
\text { between sexes in nonatopic subjects }\end{array}$ \\
\hline $\begin{array}{l}\text { OMENAAS } \\
\text { Norway, } \\
1994\end{array}$ & [17] & $\begin{array}{l}1,512 \text { subjects in four } \\
\text { groups - asthmatics - } \\
\text { nonasthmatics exposed at } \\
\text { work -nonsmokers free of } \\
\text { respiratory symptoms - } \\
\text { general population aged } \\
18-73 \text { yrs }\end{array}$ & $\begin{array}{l}\text { Higher IgE among smokers than } \\
\text { nonsmokers }\end{array}$ & $\begin{array}{l}\text { Subjects examined during the } \\
\text { summer tended to have higher IgE } \\
\text { level than those examined in } \\
\text { winter. Subjects with occpuational } \\
\text { dust or gas exposure had a higher } \\
\text { total IgE level than unexposed. } \\
\text { Levels of total IgE did not differ } \\
\text { significantly by educational level }\end{array}$ \\
\hline $\begin{array}{l}\text { JARVIS } \\
\text { England, } \\
1995\end{array}$ & [62] & $\begin{array}{l}\text { General population: two } \\
\text { samples drawn from } \\
\text { ECRHS aged } 20-44 \text { yrs: } \\
367 \text { subjects, free of } \\
\text { respiratory symptoms, } 135 \\
\text { subjects symptomatic but } \\
\text { without asthma before age } \\
14 \text { yrs }\end{array}$ & $\begin{array}{l}\text { Higher IgE among smokers than } \\
\text { nonsmokers. Difference greater } \\
\text { in females but not significant. } \\
\text { Weaker but positive associations } \\
\text { between pack-yrs and level of } \\
\text { IgE. Higher IgE among smokers } \\
\text { than nonsmokers }\end{array}$ & $\begin{array}{l}\text { In young adults, smoking explains } \\
\text { little of the variation in total IgE } \\
(<1 \%)\end{array}$ \\
\hline $\begin{array}{l}\text { LAI } \\
\text { China, } \\
1995\end{array}$ & [94] & $\begin{array}{l}\text { General population: } 195 \\
\text { subjects among } 2,032 \text { aged } \\
\geqslant 70 \text { yrs }\end{array}$ & $\begin{array}{l}\text { Higher IgE among smokers than } \\
\text { nonsmokers }\end{array}$ & \\
\hline $\begin{array}{l}\text { WüTHRICH } \\
\text { Switzerland, } \\
1996\end{array}$ & [95] & $\begin{array}{l}\text { General population: } 8,344 \\
\text { subjects aged } 18-60 \text { yrs }\end{array}$ & $\begin{array}{l}\text { Higher IgE among smokers than } \\
\text { nonsmokers }\end{array}$ & \\
\hline $\begin{array}{l}\text { SAPIGNI } \\
\text { Italy, } \\
1998\end{array}$ & [21] & $\begin{array}{l}\text { General population: } 1,905 \\
\text { subjects aged } 8-73 \text { yrs }\end{array}$ & $\begin{array}{l}\text { Higher IgE among smokers than } \\
\text { ex/nonsmokers. A dose-response } \\
\text { relationship between IgE and } \\
\text { cigarette consumption in males }\end{array}$ & $\begin{array}{l}\text { No difference between non and } \\
\text { exsmokers }\end{array}$ \\
\hline
\end{tabular}

SPT: skin-prick test; ECRHS: European Community Respiratory Health Survey.

dust or gas exposure has been described. Whether the observed association between total serum $\operatorname{IgE}$ and dust or gas exposure reflects a nonallergic inflammatory response or it reflects an allergic response due to exposure of specific occupational allergens is not known. However, it has previously been documented that some occupational allergens can induce serum specific $\operatorname{IgE}$ antibodies [18].

Finally, it is not excluded that some factors are likely to intervene directly on $\operatorname{IgE}$ assessment. In Norway, subjects seen in summer had higher IgE levels than those seen in other seasons of the year [17], probably due to pollen exposure during the summer in the Northern countries.

Skin prick test: relationship to sex, age, ethnic group, environmental factors

The reactivity to skin tests depends on age. There exists a hyporeactivity at birth which lasts until the age of 6 months. Later, the proportion of reactors begins to increase. The maximum of the reactivity curve has been seen among the young adults in various populations [9]. However, a decrease of the reactivity, differing according to the sex in individuals $>50 \mathrm{yrs}$, was seen at the age of 14 yrs in Denmark [102]. Similarly, males and females presented different patterns, the males preceding the females by 5 yrs, in the Netherlands [40]. The higher prevalence rate of skin prick reactivity during the younger age groups can represent either a process of maturation of immunological reactivity, or a longer exposure to environmental allergens. On the contrary, the decline of skin prick reactivity in the older age groups might depend either on a real decline of immunological reactivity or on a decrease of the skin's capacity to react to immunological solicitations. A loss of vascular bed and a reduction in histamine release were observed in the skin of older adults [9]. In general, there is no agreement on the role played by sex in skin test reactivity according to the literature. Some studies 
did not find any difference [103], others did find one $[102,104]$, even if only in some age groups [9].

Few endogenous factors have been related to skin test reactivity. Low gestational age was identified as risk factor for sensitization to aeroallergens at school age [105]. Low birth-weight was a significant risk for skin test reactivity at the age of 2 yrs [78]. Ethnic factors also influence skin test reactivity. In a worker population, skin test reactivity was higher in non-White individuals compared to White [103]. An Australian epidemiological survey showed that skin prick test positivity was observed more in Asian immigrants and Australian-born Asians than in Australian-born nonAsian [106].

Among environmental factors related to skin test reactivity, there are irritants, allergens and residence area. Out of irritants, tobacco active smoking is presented in table 4 . The role of allergenic exposure is indisputable. Skin test reactivity to pollens or house dust mites depends on the month of birth [78, 107]. Former cat ownership was significantly related to sensitization to cat dander [105]. Data collected in a study on 3,371 patients with diagnosis of allergic asthma, rhinitis, or both [36], showed that indoor allergen sensitization was strongly associated with asthma, while exclusive sensitization to pollens was associated primarily with rhinitis.

Living in urban, as compared with rural areas [40], or living in West, as compared with East Germany [108], is associated with an increased prevalence of sensitization to aeroallergens. Although, in recent years, a big effort has been made to reduce emissions from industries and automobile exhausts in the USA, Japan and some European countries, levels of air pollutants are still very high, especially in large urban areas. The prevalence of skin test reactivity resulted is statistically higher in urban versus rural area in the Anglo-Saxon population of the USA. In fact, a study in Japan has demonstrated that the prevalence of clinical sensitivity to cedar pollen is higher among subjects living along roads with heavy traffic but with low pollen counts in comparison with those living in cedar forests with high pollen counts but less traffic. Another study showed that the most polluted areas in the Erie county also had higher rates of eczema. Indeed, studies in animals have shown that air pollutants such as $\mathrm{SO}_{2}, \mathrm{NO}_{2}$, and $\mathrm{O}_{3}$ increase the permeability of the mucous membrane of the airway tract, favouring the development of allergic reactions [109]. Environmental tobacco exposure is a risk factor for skin test reactivity [110]. However, no demonstration of in utero exposure could be given. Smoking showed an inverse effect on skin reactivity: e.g. SHERRILL et al. [57] reported that smoking tended to be less common in skin-test reactors than in nonreactors and other authors found similar results [9, 45]. WüTHRICH et al. [95] reported that tobacco smoking is associated with increased $\mathrm{IgE}$ levels and negatively related to skin reactivity and hay fever.

Inverse associations between atopy and smoking may be explained by selection factors. Indeed, atopic subjects may be more susceptible to environmental hazards, such as the bronchial irritant effects of smoking, than the rest of the population, and, consequently, they may decide to quit or not to start smoking.

It is interesting to point out the possible interactions between smoking and atopy in affecting bronchial responsiveness. $\mathrm{O}^{\prime}$ CONNOR et al. [111] observed a higher degree of bronchial responsiveness in smokers with positive skin tests, than in smokers with negative skin tests. In multivariate models, this author observed minor additional effects of $\operatorname{IgE}$ levels and blood eosinophils on bronchial hyperreactivity and he hypothesized a synergism of cigarette smoking and skin test reactivity in affecting bronchial hyperresponsiveness.

Additional interesting observations are present in studies obtained in subjects exposed to specific irritants in occupational settings. Higher values of specific IgE or higher prevalence of subjects with positive skin tests were reported in exposed smokers when compared to nonexposed smokers [112]. These observations suggest that smoking may facilitate sensitization in exposed subjects, increasing bronchial mucosa permeability and

Table 4. - Relationship between smoking habits and skin tests reactivity among adults

\begin{tabular}{|c|c|c|c|c|}
\hline Authors & [Ref.] & Subjects & Findings & Comments \\
\hline $\begin{array}{l}\text { MENSINGA } \\
\text { the Netherlands, } \\
1990\end{array}$ & [45] & $\begin{array}{l}\text { General population: } \\
3,258 \text { subjects } \\
\text { aged } 14-39 \text { yrs }\end{array}$ & $\begin{array}{l}\text { Inverse association between } \\
\text { positive skin test reactivity } \\
\text { and cigarette smoking in } \\
\text { males but not in females }\end{array}$ & Scratch method \\
\hline $\begin{array}{l}\text { NIELSEN } \\
\text { Denmark, } \\
1994\end{array}$ & {$[102]$} & $\begin{array}{l}\text { General population: } \\
793 \text { subjects } \\
\text { aged } 15-69 \text { yrs }\end{array}$ & $\begin{array}{l}\text { Higher prevalence of positive } \\
\text { SPT in nonsmokers than in } \\
\text { current smokers, more marked } \\
\text { in males }\end{array}$ & $\begin{array}{l}\text { Lancet. Adjusted for sex and } \\
\text { age, exsmokers intermediate } \\
\text { between nonsmokers and smokers } \\
\text { for skin reactivity }\end{array}$ \\
\hline $\begin{array}{l}\text { MENSINGA } \\
\text { the Netherlands, } \\
1994\end{array}$ & [40] & $\begin{array}{l}\text { General population: } \\
2,875 \text { subjects } \\
\text { aged } 17-49 \text { yrs }\end{array}$ & $\begin{array}{l}\text { No association between SPT } \\
\text { reactivity and smoking habits }\end{array}$ & $\begin{array}{l}\text { Similar results in light and heavy } \\
\text { smokers }\end{array}$ \\
\hline $\begin{array}{l}\text { BALDACCI } \\
\text { Italy, } \\
1996\end{array}$ & [9] & $\begin{array}{l}\text { General population: } \\
2,649 \text { subjects } \\
\text { aged } 8-75 \text { yrs }\end{array}$ & $\begin{array}{l}\text { No effect of smoking on SPT, } \\
\text { but a trend in nonsmokers to } \\
\text { have higher SPT positivity }\end{array}$ & \\
\hline $\begin{array}{l}\text { WÜTHRICH } \\
\text { Switzerland, } \\
1996\end{array}$ & [95] & $\begin{array}{l}\text { General population: } \\
8,344 \text { subjects } \\
\text { aged } 18-60 \text { yrs }\end{array}$ & $\begin{array}{l}\text { Higher prevalence of positive } \\
\text { SPT in nonsmokers than in } \\
\text { current smokers }\end{array}$ & $\begin{array}{l}\text { Difference between former smokers } \\
\text { and nonsmokers, more pronounced } \\
\text { in males }\end{array}$ \\
\hline
\end{tabular}

SPT: skin-prick test. 
thus facilitating and enhancing allergen penetration in the respiratory mucosa.

Various occupational exposures have been related to skin test reactivity [103]. Surprisingly, skin test reactivity depends also on the period of the survey. House dust mite reactivity was more frequent in subjects seen during the winter compared to the others [104]. Finally, it is well known that various medications may reduce the skin tests reactivity. Medication intake must be taken into account in the study of skin reactions.

Eosinophilia: relationship to sex, age, ethnic group, environmental factors

The eosinophil is an inflammatory cell involved in pulmonary disorders, mainly allergic. Both tissue and circulating eosinophils are involved, but only peripheral blood eosinophils have been considered in epidemiological studies. Population-based data have shown that peripheral blood eosinophilia is related to asthma prevalence and acute attacks, bronchial hyperresponsiveness, and decreased lung function level and decline [13, 43, 44]. Eosinophils are strongly related to age in childhood [113]. The relationship is unclear in adulthood [114]. Children have a higher eosinophil count than adults. The maximum of the distribution is observed at the age of 4-8yrs. However, an epidemiological survey conducted in the Netherlands could not find any association [40]. Similarly, the relationship to sex is unclear. Eosinophilia defined as $\geqslant 275$ cells $\cdot \mathrm{mm}^{-3}$ was more frequent in males than in females $[45,115]$. This was not confirmed by other studies [113, 116]. Results from studies on the role of ethnic group are contradictory. Black individuals are likely to have higher eosinophil counts [115, 117], but this has not been confirmed [118, 119]. Other biological sources of variation of eosinophil count have been identified: exercise, emotional stress, physical abuse, diurnal variation beta-adrenergic agents and hormonal influence of the menstrual source [114]. However, few epidemiological evidence exists. Interpretation of results on eosinophils must consider the fact that various cut-off values have been proposed so that comparisons are not allowed. Few studies have reported on the effects of tobacco smoking on eosinophilia (table 5).

Eosinophils are also influenced by residence area and pollution. Urban residents are at higher risk of eosinophilia than rural residents [40]. Similarly, a difference in eosinophil count was seen between the

Table 5. - Relationship between smoking habits and eosinophilia

\begin{tabular}{|c|c|c|c|c|}
\hline Authors & [Ref.] & Subjects & Findings & Comments \\
\hline $\begin{array}{l}\text { RONCHETTI } \\
\text { Italy, } \\
1990\end{array}$ & [97] & $\begin{array}{l}179 \text { children } \\
\text { aged } 9 \text { yrs }\end{array}$ & $\begin{array}{l}\text { Children whose parents smoke } \\
\text { have increased absolute counts } \\
\text { and percentages }(\geqslant 4 \%) \text { of } \\
\text { eosinophils; effect only } \\
\text { significant in male children }\end{array}$ & $\begin{array}{l}\text { Similar effect for paternal and } \\
\text { maternal smoking. Eosinophilia } \\
\text { increases with number of smoking } \\
\text { parents in males, only a trend in } \\
\text { females (small minority of mothers } \\
\text { smoked) }\end{array}$ \\
\hline $\begin{array}{l}\text { MENSINGA } \\
\text { the Netherlands, } \\
1990\end{array}$ & [45] & $\begin{array}{l}\text { General population: } \\
3,258 \text { subjects } \\
\text { aged } 14-39 \text { yrs }\end{array}$ & $\begin{array}{l}\text { Current smoking related to } \\
\text { higher eosinophil counts. } \\
\text { Association stronger for heavy } \\
\text { smokers }\left(\geqslant 15 \text { cigarettes } \cdot \text { day }^{-1}\right) \\
\text { than light smokers }\end{array}$ & $\begin{array}{l}\text { Elevated eosinophil count associated } \\
\text { with males versus females. No } \\
\text { relation of eosinophil counts } \\
\text { between exsmokers and nonsmokers }\end{array}$ \\
\hline
\end{tabular}

SCHWARTZ
USA,

1994

\begin{tabular}{|c|c|c|}
\hline $\begin{array}{l}\text { EL-NAWAWY } \\
\text { Egypt, } \\
1996\end{array}$ & [120] & $\begin{array}{l}120 \text { subjects } \\
\text { mean aged } 10 \mathrm{yrs}\end{array}$ \\
\hline $\begin{array}{l}\text { JENSEN } \\
\text { Denmark, } \\
1998\end{array}$ & [121] & $\begin{array}{l}298 \text { smoking } \\
\text { volunteers and } 136 \\
\text { random controls; } \\
\text { follow-up } 6 \text { months; } \\
\text { mean age } 44.2 \text { yrs }\end{array}$ \\
\hline $\begin{array}{l}\text { ULRIK } \\
\text { Denmark, } \\
1998\end{array}$ & [43] & $\begin{array}{l}665 \text { adolescents aged } \\
13-23 \text { yrs }\end{array}$ \\
\hline $\begin{array}{l}\text { SUNYER } \\
\text { USA, } \\
1996\end{array}$ & [122] & $\begin{array}{l}2,435 \text { men aged } \\
>18 \text { yrs }\end{array}$ \\
\hline
\end{tabular}

Eosinophils positively associated with the current number of cigarettes smoked per day. No effect of pack-years and years since quitting. Increased cigarette smoking decreased percent eosinophils counts Children whose parents smoke have increased absolute counts of eosinophils, effect only significant in male children No significant differences between smokers and nonsmokers for eosinophil counts and percentage

Association between daily tobacco consumption and eosinophil count approached the level of statistical significance. No effect of packyears and eosinophil counts Eosinophil percentage positively associated with cigarettes pack. day $^{-1}$ smoked
Multiple regression models controlled for age, sex, ethnic group and body mass index. No differences in eosinophils between males and females

Passive smoking increased eosinophil counts in children with frequent respiratory symptoms compared to others

AIDS cohort study, homosexual/ bisexual volunteer men (AIDS-free) from four US sites

AIDS: acquired immunodeficiency syndrome. 
subjects living in an area polluted by sulphur dioxide and fluoride than in an unpolluted area in Norway. Furthermore, a recent exposure was related to a higher eosinophilia [123].

\section{Relationship among skin reactivity, IgE, eosinophilia and respiratory health outcomes}

Skin test reactivity has been used to categorize individuals as atopic or nonatopic. However, eosinophilia and elevated serum IgE levels, which correlate with skin test reactivity, have also been used in many studies as alternative methods to characterize atopic subjects. These three main phenotypic markers are commonly utilized to identify the "atopic" state.

Indeed, different categories of respiratory symptoms and conditions may be associated with different phenotypic markers. For instance, Burrows et al. [4] have reported that asthma, in a random sample of residents in Tucson, Arizona, was strongly correlated with ageand sex-adjusted serum IgE level, independently of skin test reactivity; on the contrary, hay fever was closely associated with skin test reactivity to a set of common aeroallergens.

In another population-based study in The Netherlands, Mensinga et al. [45] analysed the relationship of eosinophilia and skin test reactivity to respiratory symptoms. They reported an association of eosinophilia with chronic cough, bronchitis, and dyspnoea, while skin test positivity and eosinophilia together were associated with persistent wheeze and asthma attacks. Tollerud et al. [12], in the Normative Aging Study, found a significant association of skin test positivity with hay fever, but not with symptoms of wheeze or cough and phlegm. Eosinophilia was associated with asthma and with phlegm production, and serum total IgE concentration was more strongly associated with asthma. In the second survey on the Italian general population study of Po river Delta [124], IgE and skin prick reactivity resulted associated with asthma and rhinitis. However, IgE appeared more closely associated with asthma while skin prick reactivity showed a moderately stronger association with rhinitis. Furthermore, cough was also significantly associated with skin reactivity, but only in females [9]. In the same general population the relationship between skin reactivity and total IgE level was found to vary with the specific categories of allergens: it was significant for house-dust mites and pollens, but not for moulds and animal danders. Therefore, both biomarkers of atopy should be used in epidemiological studies [21].

STEIN et al. [125] demonstrated that methacholine responsiveness, peak flow variability and markers of atopy (total IgE and skin test reactivity) identify three different wheezing phenotypes in childhood: "transient early wheezing" limited to the first three years of life and unrelated to increased airway lability; "nonatopic wheezing" of the infancy and early school years associated with positive peak flow variability but not with hyperresponsiveness; and "IgE-associated wheeze/ asthma" associated with persistent wheezing at any age and with methacholine hyperresponsiveness, peak flow variability, and markers of atopy.
Also the Dutch ECRHS Group [126] confirmed the close relationship of skin test positivity with reported symptoms of nasal allergy in a general population. In particular, for each tested allergen, a skin test positivity together with a positive specific IgE measurement were the best predictors of the corresponding nasal symptoms. High levels of total IgE may be considered an indicator of greater dysregulation of the immune system in atopic allergy. Eosinophil count may be considered an aspecific indicator of nasal allergy as it was associated with all nasal symptom groups: symptoms due to exposure to indoor allergens only, symptoms due to exposure to outdoor allergens only, and symptoms due to exposure to both indoor and outdoor allergens.

In a Spanish study [127], the two markers of atopy, total IgE and skin test reactivity, were found differently related to bronchial asthma according to the different stages of life: skin test reactivity was more useful as a predictive factor in children, while IgE determination was more useful in adults.

Moreover, blood eosinophilia at 3 months of age has been found to correlate significantly to cord blood $\operatorname{IgE}$ levels and to skin prick test reactivity later on during a follow-up period of 18 months. Furthermore, the association between increased blood eosinophil counts and a subsequent diagnosis of atopic disease suggests the main predictive role of this atopic marker [41]. On the contrary, an increased basophil count at birth was not a good predictive marker of atopy [128]. In addition, TERHO et al. [10], investigating the predictive value of skin reactivity, smoking, and living in a farming environment in the development of chronic bronchitis, found that atopy and smoking seemed to have an additive effect on both the prevalence and incidence of chronic bronchitis, thus supporting the socalled "Dutch hypothesis" about the natural history of chronic bronchitis [129].

Many studies, exploring the natural history of asthma and its relation to allergic responses, have examined the relation between airway hyperresponsiveness and atopy. PEAT et al. [130] reported that young adults who are sensitized to common allergens have a high chance to get airway hyperresponsiveness, even in the absence of symptoms; this is further evidence of the fundamental role of IgE-mediated responses in the natural history of airway hyperresponsiveness throughout childhood and adulthood. Phenotypes of asthma described by IgE, SPT and eosinophilia in children and adults have been reported [131] and discussed with regard to criteria applied in studies and their limitations [132]. Figure 3 depicts the number of adults and children with atopy according to the three classic definitions: any skin wheal $\geqslant 3 \mathrm{~mm}$, total $\mathrm{IgE}$ level $\geqslant 100 \mathrm{kU} \cdot \mathrm{L}^{-1}$ and blood eosinophilia $>5 \%$. It showed that $8.5 \%$ of asthmatic adults and $1.5 \%$ of asthmatic children were not atopic by any criterion and that there was some heterogeneity, particularly in adults.

In several cross-sectional studies, total serum $\mathrm{IgE}$ has been related to reduced pulmonary function, a marker of obstructive lung disease [45, 65, 133-137]. In recent longitudinal studies, elevated total serum IgE has also been related to an increased rate of 
a)

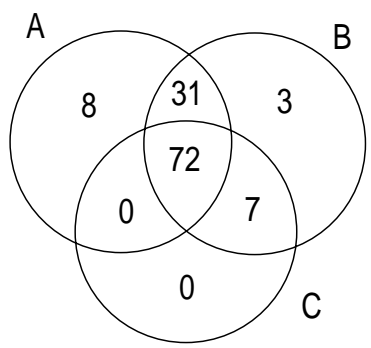

b)

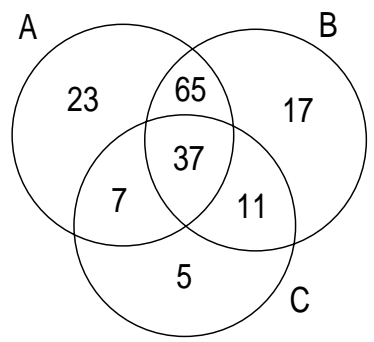

Fig. 3. - Comparison of asthma phenotypes in: a) 135 children, (2 subjects with missing data) and b) 213 adults (18 subjects with missing data), of the Epidemiological Study of the Genetics and Environment of Asthma, Bronchial Hyperresponsiveness, and Atopy (EGEA). The following intermediate phenotypes are described in asthmatic probands of the EGEA study: A: skin prick testing (SPT) $(\geqslant 3 \mathrm{~mm})$; B: total serum $\operatorname{IgE}(\operatorname{IgE}) \geqslant 100 \mathrm{IU} \cdot \mathrm{mL}^{-1}$; and $\mathrm{C}$ : blood eosinophilia (Eosinophils) $>5 \%$ for 30 adults and 12 children, at least on the data was missing. Adapted from reference [132].

decline in pulmonary function of nonsmokers and exsmokers [135] as well as smokers [138]. Thus, elevated total serum IgE has been suggested as a possible risk factor for developing obstructive lung disease as well as being significantly associated with the asthmatic phenotype [136].

Why is there a relationship between total serum $\mathrm{IgE}$ and airways obstruction? Increased permeability of the airways to less frequently encountered allergens could be one explanation [139]. In smokers, another explanation may be the effects of smoking on leukocytes in the lung and the peripheral blood including the lymphocytes and "dysregulation" of cytokines $[90,140]$. IgE appears to be a biomarker of changed or impaired lymphocyte-cytokine activity which has a significant contribution in causing obstructive lung disease, and especially chronic obstructive lung disease [140]. In nonsmokers and especially in those without atopy one or more other unrecognized factors may be relevant for obstructive lung disease.

The lack of a relationship by specific allergy and pulmonary function has been reported [46, 133, 141]. However, all these investigators have used a grouped variable including one or more specific allergens and may thus have obscured any significant relationship between specific allergy and reduced lung function level. In children with atopy to HDM or cat, however, there has been observed an impaired growth in lung function, as assessed by spirometry, from 9-15 yrs [142].

In adults from a general population there was observed a dose-response relationship between HDM antibody levels and reduced lung function indicating a causal relationship [143]. House dust mite allergy in selected groups of adults has been associated with asthmatic phenotype [144]. Even among elderly, allergic sensitization (atopy) has been associated with a more rapid decline in FEV1 than in those without atopy [140]. A clinical study suggests that moving to "healthy homes" with a reduction in house dust mite exposure give improvements in FEV1, in medicine score, in symptom score and in total serum IgE [145].
Some [146, 147], but not all studies [143] in general populations of adults have observed a significant association between total serum $\operatorname{IgE}$ and nonspecific bronchial responsiveness after adjusting for confounders. In a survey limited to subjects with obstructive lung disease there was also an association between increasing total serum IgE levels and bronchial responsiveness, while not with increasing number of serum specific IgE antibodies [148]. Furthermore, a longitudinal study of children [151] observed that the overall tendency to bronchial responsiveness and the tendency to retain bronchial responsiveness were closely related to total serum $\mathrm{IgE}$.

In children, there has been found a relationship between allergic sensitization (atopy) and nonspecific bronchial responsiveness in cross-sectional and longitudinal studies [93, 149-151]. This has been suggested to include primarily indoor allergens. Atopy may reflect a tendency to overproduce mediators in response to allergen-exposure, while nonspecific bronchial responsiveness may reflect the propensity of the target cells in the bronchi to respond to allergy-related mediators such as histamine [152].

Recent reports have observed a relationship between serum specific IgE antibodies and bronchial responsiveness in young adults, but it may be limited to some allergens at least in adults [143, 146, 147, 153, 154].

\section{Conclusion}

Epidemiological evidence confirms that different groups of respiratory symptoms and conditions may be associated with distinct phenotypic markers.

In fact, many pertinent studies have demonstrated a closer relationship of total IgE to asthma and a stronger association between skin reactivity and rhinitis [4, 12, 124], but there are also other findings that suggest a relationship of atopic predisposition, as assessed by prick test reactions or eosinophilia, to other respiratory problems, in particular, those chronic bronchitis related, supporting the "Dutch hypothesis" $[45,129]$. Thus, future investigations will be devoted to developing a more precise and consistent definition of atopy which is a prerequisite for elucidating the complex relationship among atopy, respiratory disease susceptibility and respiratory health outcome.

Furthermore, longitudinal population studies are required to amplify the cross sectional observations, in fact they will be more and more important in order to determine in which period of life the onset of the atopic status is prognostically relevant. These studies will also allow evaluation of the relationship of the age of onset and the severity of atopy with the persistence and the severity of respiratory symptoms. As exposure and sensitization to certain allergens have shown a close relation with clinical diagnoses, there is an urgent need to assess procedures of allergen avoidance and of reducing allergens in the environment to determine the effect on patient symptoms, exacerbation rate, use of medication and health costs evaluation. 


\section{References}

1. Rapaport HG. Clemens von Pirquet and allergy. Ann Allergy 1973; 31: 467-75.

2. Van Arsdel PP, Larson EB. Diagnostic tests for patients with suspected allergic disease. Ann Intern Med 1989; 110: 304-312.

3. Coca AF, Cooke RA. On the classification of the phenomena of hypersensitiveness. A study of atopic reagines. J Immunol 1923; 8: 163-171.

4. Burrows B, Martinez FD, Halonen M, Barbee RA, Cline MG. Association of asthma with serum IgE levels and skin-test reactivity to allergens. $N$ Engl J Med 1989; 320: 271-277.

5. Bousquet J, Lockey R, Malling H-J. WHO Position Paper. Allergen immunotherapy: therapeutic vaccines for allergic diseases. Allergy 1998; 53: (Suppl.), 5-42.

6. Sunyer J, Anto J, Kogevinas M, et al. Risk factors for asthma in young adults. Eur Respir J 1997; 10: 2490 2494.

7. Hulka B, Margolin B. Methodological issues in epidemiologic studies using biologic markers. $\mathrm{Am} \mathrm{J}$ Epidemiol 1992; 135: 200-209.

8. Merrett T. Quantification of $\operatorname{IgE}$ both as total immunoglobulin and as allergen-specific antibody. In: Kay A, ed. Allergy and allergic diseases. Oxford, Blackwell Science, 1997; pp. 1012-1034.

9. Baldacci S, Modena $\mathrm{P}$, Carrozzi L, et al. Skin prick test reactivity to common aeroallergens in relation to total $\mathrm{IgE}$, respiratory symptoms, and smoking in a general population sample of northern Italy. Allergy 1996; 51: $149-156$.

10. Terho EO, Koskenvuo M, Kaprio J. Atopy: a predisposing factor for chronic bronchitis in Finland. J Epidemiol Community Health 1995; 49: 296-298.

11. Weller PF, Lim K, Wan HC, et al. Role of the eosinophil in allergic reactions. Eur Respir J 1996; 9: $109 \mathrm{~s}-115 \mathrm{~s}$.

12. Tollerud DJ, O'Connor GT, Sparrow D, Weiss ST. Asthma, hay fever and phlegm production associated with distinct patterns of allergy skin test reactivity, eosinophilia, and serum IgE levels. Am Rev Respir Dis 1991; 144: 776-781.

13. Jansen DF, Rijcken B, Schouten JP, et al. The relationship of skin test positivity, high serum total IgE levels, and peripheral blood eosinophilia to symptomatic and asymptomatic airway hyperresponsiveness. Am J Respir Crit Care Med 1999; 159: 924-931.

14. Pepys J. Atopy. In: Gill P, Coombs R, Lachmann P, eds. Clinical Immunology. 3rd edn. Oxford, Blackwell Science, 1975; pp. 877-902.

15. Jarvis D, Burney P. Epidemiology of atopy and atopic disease. In: Kay A, ed. Allergy and allergic diseases. Oxford, Blackwell Science, 1997; pp. 1208-1224.

16. Burney P, Malmberg E, Chinn S, Jarvis D, Luczynska C, Lai E. The distribution of total and specific serum IgE in the European Community Respiratory Health Survey. J Allergy Clin Immunol 1997; 99: 314-322.

17. Omenaas E, Bakke P, Elsayed S, Hanoa R, Gulsvik A. Total and specific serum IgE levels in adults: relationship to sex, age and environmental factors. Clin Exp Allergy 1994; 24: 530-539.

18. Zetterström O, Osterman K, Machado L, Johansson S. Another smoking hazard: raised serum IgE concentration and increased risk of occupational allergy. BMJ 1981; 283: 1215-1217.

19. Burr M, Leger A, Bevan C, Merrett T. A community survey of asthmatic characteristics. Thorax 1975; 30: 663-668.

20. Cline M, Burrows B. Distribution of allergy in a population sample residing in Tucson, Arizona. Thorax 1989; 44: 425-431.

21. Sapigni T, Biavati P, Simoni M, et al. The Po River Delta Respiratory Epidemiological Survey: an analysis of factors related to level of total serum IgE. Eur Respir J 1998; 11: 278-283.

22. Mensinga T, Scouthen J, Weiss S, Kauffmann H, Speizer F, Van der Lende R. The relationship between allergy, respiratory symptoms, and pulmonary function. In: Sluiter H, Van der Lende R, eds. Bronchitis IV. Assen, Royal van Gorcum, 1989; pp. 35-41.

23. Gassner M. Immunological-allergological reactions with changed environmental conditions. Schweiz Rundsch Med Prax 1992; 81: 426-430.

24. Nakagomi $T$, Itaya $H$, Tominage $T$, Yamaki $M$, Hisamatsu S, Nakagomi O. Is atopy increasing?. Lancet 1994; 343: 121-112.

25. Colloff MJ, Ayres J, Carswell F, et al. The control of allergens of dust mites and domestic pets: a position paper. Clin Exp Allergy 1992; 22: (Suppl.), 1-28.

26. Van Metre TE, Adkinson NF, Kagey-Sobotka A, Marsh DG, Norman PS, Rosenberg GL. How should we use skin testing to quantify IgE sensitivity? $J$ Allergy Clin Immunol 1990; 86: 583-627.

27. Peat JK, Woolcock AJ. Sensitivity to common allergens: relation to respiratory symptoms and bronchial hyperresponsiveness in children from three different climatic areas of Australia. Clin Exp Allergy 1991; 21: 573-581.

28. Baldacci S, Carrozzi L, Viegi G, Giuntini C. Assessment of respiratory effect of air pollution: study design on general population samples. JEPTO 1997; 16: 7783.

29. Haahtela T, Björksten F, Heiskala M, Suoniemi I. Skin prick test reactivity to common allergens in Finnish adolescents. Allergy 1980; 35: 425-431.

30. Barbee RA, Lebowitz MD, Thompson HC, Burrows B. Immediate skin-test reactivity in a general population sample. Ann Intern Med 1976; 84: 129-133.

31. Sin A, Köse S, Terzioglu E, Kokuludag A, Sebik F, Kabakçi T. Prevalence of atopy in young healthy population, in Izmir, Turkey. Allergol Immunopathol 1997; 25: 80-84.

32. Nowak D, Heinrich J, Jörres R, et al. Prevalence of respiratory symptoms, bronchial hyperresponsiveness and atopy among adults: west and east Germany. Eur Respir J 1996; 9: 2541-2552.

33. Herxheimer H, McInroy P, Sutton KH. The evaluation of skin tests in respiratory allergy. Acta Allergol 1954; 7: 380-396.

34. Freidhoff LR, Meyers DA, Bias WB, Chase GA, Hussain R, Marsh DG. A genetic-epidemiologic study of human immune responsiveness to allergens in an industrial population. I. Epidemiology of reported allergy and skin test positivity. Am J Med Genet 1981; 9: $323-340$.

35. Sibbald B, Rink E. Epidemiology of seasonal and perennial rhinitis: clinical presentation and medical history. Thorax 1991; 46: 895-901.

36. Boulet LP, Turcotte H, Laprise C, et al. Comparative degree and type of sensitization to common indoor and outdoor allergens in subjects with allergic rhinitis and/or asthma. Clin Exp Allergy 1997; 27: 52-59.

37. Dreborg S. Standardization of allergenic preparations 
by in vitro and in vivo methods. Allergy 1993; 48: 6370 .

38. Viegi G, Diviggiano E, Carrozzi L, Vellutini M, Prediletto R. Distribuzione della cutireattività agli allergeni respiratori in un sottocampione della popolazione generale. Lotta contro la TBC e malattie polmonari soc 1987 ; 3: 573-576.

39. Venge P. The eosinophil. In: Godard P, Bousquet J, Michel FB, eds. Advances in allergology and clinical immunology. ed. Parthenon Publishing Group, 1992; pp. $175-185$.

40. Mensinga TT, Schouten JP, Rijcken B, Weiss ST, Van der lende R. Host factors and environmental determinants associated with skin test reactivity and eosinophilia in a community-based population study. Ann Epidemiol 1994; 4: 382-392.

41. Borres MP, Odelram H, Irander K, Kjellman NI, Björksten B. Peripheral blood eosinophilia in infants at 3 months of age is associated with subsequent development of atopic disease in early childhood. J Allergy Clin Immunol 1995; 95: 694-698.

42. Kajosaari M, Saarinen UM. Evaluation of laboratory tests in childhood allergy. Total serum IgE, blood eosinophilia and eosinophil and mast cells in nasal mucosa of 178 children aged 3 years. Allergy 1981; 36: 329-335.

43. Ulrik CS. Eosinophil and pulmonary function: An epidemiologic study of adolescents and young adults. Ann Allergy Asthma Immunol 1998; 80: 487-493.

44. Mensinga TT, Schouten JP, Weiss ST, van der Lende $\mathrm{R}$. Relationship of skin test reactivity and eosinophilia to level of pulmonary function in a community-based population study. Am Rev Respir Dis 1992; 146: 638643.

45. Mensinga T, Schouten J, Rijcken B, Weiss S, Speizer F, Van der Lende R. The relationship of eosinphilia and positive skin test reactivity to respiratory symptom prevalence in a community-based study. J Allergy Clin Immunol 1990; 86: 99-107.

46. Taylor R, Gross E, Joyce H, Holland F, Pride N. Smoking, allergy, and the differential white blood cell count. Thorax 1985; 40: 17-22.

47. Kauffmann D, Annesi I, Oryszczyn MP. The relationship between smoking and allergy. In: Sluiter HJ, Van der Lende R, eds. Bronchitis IV. Assen, Van Gorcum, 1989; pp. 57-70.

48. Taylor KL, Luksza AR. Peripheral blood eosinophil counts and bronchial responsiveness. Thorax 1987; 42: $542-556$.

49. Meyers D, Postma D, Panhuysen C, et al. Evidence for regulating total serum IgE levels mapping to chromosome 5. Genomics 1994; 23: 464-470.

50. Cookson W, Sharp P, Lynch J, Faux A, Hopkin J. Linkage between immunoglobulin $\mathrm{E}$ responses underlying asthma and rhinitis and chromosome 11q. Lancet 1989; i: 1292-1295.

51. Hanson B, Kronenburg R, Johnson B, Blumenthal M. Pulmonary function, serum IgE levels and specific IgE immune responses in monozygotic twins reared apart. J Allergy Clin Immunol 1985; 75: 155.

52. Hopkins J. The genetics of asthma. Arch Dis Child 1993; 68: 721-723.

53. The European Community Respiratory Health Survey Group. Genes for asthma? An analysis of the European Community Respiratory Health Survey. Am J Respir Crit Care Med 1997; 156: 1773-1780.

54. Marone G, Poto S, Clesino D, Bonini S. Human basophil releasability. III. Genetic control of human basophil releasability. J Immunol 1986; 137: 35883592 .

55. Magnusson CGM. Maternal smoking influence cord serum IgE and IgD levels increase the risk for subsequent infant allergy. J Allergy Clin Immunol 1986; 78: 898-904.

56. Johnson CC, Peterson EL, Ownby DR. Gender differences in total and allergen-specific Immunoglobulin $\mathrm{E}$ ( $\mathrm{IgE}$ ) concentrations in a populationbased cohort from birth to age four years. Am J Epidemiol 1998; 147: 1145-1152.

57. Sherrill D, Halonen M, Burrows B. Relationships between total serum IgE, atopy, and smoking: a twenty-year follow-up analysis. J Allergy Clin Immunol 1994; 94: 954-962.

58. Merrett T, Burr M, St Leger A, Merrett J. Circulating IgE levels in the over-seventies. Clin Allergy 1980; 10: 433-439.

59. Haahtela T, Jaakonmäki I. Relationship of allergenspecific IgE antibodies, skin prick tests and allergic disorders in unselected adolesents. Allergy 1981; 36: 251-256.

60. Gergen P, Turkeltaub P, Kovar M. The prevalence of allergic skin test reactivity to eight common aeroallergens in the U.S. population: results from the second National Health and Nutrition Examination Survey. J Allergy Clin Immunol 1987; 80: 669-679.

61. Barbee R, Halonen M, Lebowitz M, Burrows B. Distribution of $\operatorname{IgE}$ in a community population sample: correlations with age, sex, and allergen skin test reactivity. J Allergy Clin Immunol 1981; 68: 106111 .

62. Jarvis D, Luczynska C, Chinn S, Burney P. The association of age, gender and smoking with total $\mathrm{IgE}$ and specific IgE. Clin Exp Allergy 1995; 25: 1083-1091.

63. Petridou E, Kanariou M, Liatsis M, et al. Factors influencing serum immunoglobulin E levels in Greek children. Allergy 1995; 50: 210-214.

64. Oryszczyn M, Annesi I, Neukirch F, Dore M, Kauffmann F. Relationship of total IgE level, skin prick test response, and smoking habits. Ann Allergy 1991; 67: 355-359.

65. Jensen E, Pedersen B, Schmidt E, Dahl R. Serum IgE in nonatopic smokers, nonsmokers, and recent exsmokers: Relation to lung function, airway symptoms, and atopic predisposition. J Allergy Clin Immunol 1992; 90 : 224-229.

66. Grundbacher FJ, Massie FS. Levels of immunoglobulin $\mathrm{G}, \mathrm{M}, \mathrm{A}$ and $\mathrm{E}$ at various ages in allergic and non allergic black and white individuals. J Allergy Clin Immunol 1985; 75: 651-658.

67. Haus M, Heese HD, Weinberg EG, Potter PC, Hall JM, Malherbe D. The influence of ethnicity, an atopic family history, and maternal ascariasis on cord blood serum IgE concentrations. J Allergy Clin Immunol 1988; 82: 179-189.

68. Oryszczyn MP, Annesi-Maesano I, Campagna D, Sahuquillo J, Huel G, Kauffmann F. Head circumference at birth and maternal factors related to cord blood IgE. Clin Exp Allergy 1999; 29: 334-341.

69. Godfrey KM, Barker DJP, Osmond C. Disporportionate fetal growth and raised $\operatorname{IgE}$ concentration in adult life. Clin Exp Allergy 1994; 24: 641-648.

70. Vellutini M, Viegi G, Parrini D, et al. Serum immunoglobulins E are related to menstrual cycle. Eur J Epidemiol 1997; 13: 931-935. 
71. Pope A, Patterson R, Burge H. Indoor allergens. Assessing and controlling adverse health effects Washington D.C., National Academy Press, 1993.

72. Platts-Mills T, Sporik R, Ward G, et al. Dose-response relationships between asthma and exposure to indoor allergens. Progr Allergy Clin Immunol 1995; 3: 90-96.

73. Sporik R, Holgate S, Platts-Mills T, Cogswell J. Exposure to house-dust mite allergen (Der p I) and the development of asthma in childhood. $N$ Engl $\mathrm{J} \mathrm{Med}$ 1990; 323: 502-507.

74. Luczynska C, Li Y, Chapman M, Platts-Mills T. Airborne concentratuions and particle size distribution of allergen derived from domestic cats (Felis domesticus): Measurements using cascade impactor, liquid impinger and two site monoclonal antibody assay Fel dI. Am Rev Respir Dis 1990; 141: 361-367.

75. Seaton A, Gooden D, Brown K. Increase in asthma: a more toxic environment or a more susceptible population. Thorax 1994; 49: 36-41.

76. Peat J, van den Berg R, Green W, Mellis CM, Leeder SR, Woolcock AJ. Changing prevalence of asthma in Australian children. BMJ 1994; 308: 1591-1596.

77. Harving H, Korsgaard J, Dahl R. House dust mites and associated environmental conditions in Danish homes. Allergy 1993; 48: 106-109.

78. Rugtveit J. Environmental factors in the first month of life and the possible relationship to later development of hypersensitivity. Allergy 1990; 45: 154-156.

79. Burr M, Limb E, Maguire M, et al. Infant feeding, wheezing and allergy: a prospective study. Arch Dis Child 1993; 68: 724-728.

80. Bjerke T, Hedegaard M, Henriksen TB, Nielsen BW, Schitz PO. Several genetic and environmental factors influence cord blood $\operatorname{IgE}$ concentration. Pediatr Allergy Immunol 1995; 5: 88-94.

81. Berciano FA, Crespo M, Bao CG, Alvarez FV. Serum levels of total $\mathrm{IgE}$ in non-allergic children. Influence of genetic and environmental factors. Allergy 1987; 42: 276-283.

82. Von Mutius E, Martinez F, Fritzsch C, Nicolai T, Reitmeir $\mathrm{P}$, Thiemann $\mathrm{H}$. Skin test reactivity and number of siblings. BMJ 1994; 308: 692-695.

83. Strachan D, Griffiths J, Anderson H, Johnston I. Allergic sensitisation and position in the sibship: a national study of young British adults. Thorax 1994; 49: 1053P

84. Wjst M, Heinrich J, Liu P, et al. Indoor factors and IgE levels in children. Allergy 1994; 49: 766-771.

85. Shirakawa T, Enomoto T, Shimazu S, Hopkin J. The inverse association between tuberculin responses and atopic disorder. Science 1997; 275: 77-79.

86. Shaheen S, Aaby P, Hall A, et al. Measles and atopy in Guinea-Bissau. Lancet 1996; 347: 1792-1796.

87. Burrows B, Halonen M, Barbee R, Lebowitz M. The relationship of serum immunoglobulin $\mathrm{E}$ to cigarette smoking. Am Rev Respir Dis 1981; 124: 523-525.

88. Romagnani S, Ricci M. Present views on the regulation of human IgE synthesis. ACI News 1990; 2: 192 196.

89. Bloom J, Halonen M, Dunn A, Pinnas J, Burrows B. Pneumococcus-specific immunoglobulin $\mathrm{E}$ in cigarettes smokers. Clin Allergy 1986; 16: 25-32.

90. Holt P. Immune and inflammatory function in cigarette smokers. Thorax 1987; 42: 241-249.

91. Osterman K, Zetterström O, Johansson S. Coffee worker's allergy. Allergy 1982; 37: 313-322.

92. Sunyer J, Anto J, Sabria J, et al. Risk factors of soybean epidemic asthma. Am Rev Respir Dis 1992; 145: 1098-1102.

93. Backer V, Ulrik CS, Wendelboe D, et al. Distribution of serum $\operatorname{IgE}$ in children and adolescents aged 7 to 16 years in Copenhagen, in relation to factors of importance. Allergy 1992; 47: 484 489.

94. Lai CKW, Ho SC, Lau J, et al. Respiratory symptoms in elderly chinese living in Hong Kong. Eur Respir $J$ 1995; 8: 2055-2061.

95. Wüthrich B, Schindler C, Medici TC, Zellweger JP, Leuenberger PH, the SAPALDIA team. IgE levels, atopy markers and hay fever in relation to age, sex and smoking status in a normal adult swiss population. Int Arch Allergy Immunol 1996; 111: 396-402.

96. Michel F, Bousquet J, Greillier P, Robinet-Levy M, Couloumb Y. Comparison of cord blood IgE concentrations and maternal allergy for the prediction of atopic diseases in infancy. $J$ Allergy Clin Immunol 1980; 65: 422-430.

97. Ronchetti R, Macri F, Ciofetta G, et al. Increased serum $\operatorname{IgE}$ and increased prevalence of eosinophilia in 9 year old children of smoking parents. $J$ Allergy Clin Immunol 1990; 86: 400-407.

98. Arshad S, Stevens M, Hide D. The effect of genetic and environmental factors on the prevalence of allergic disorders at the age of two years. Clin Exp Allergy 1993; 23: 504-511.

99. Martinez F, Antognoni G, Macri F, et al. Parenteral smoking enhances bronchial responsiveness in nineyear-old children. Am Rev Respir Dis 1988; 138: 518523.

100. Strachan DP, Cook DG. Health effects of passive smoking. 5. Parental smoking and allergic sensitization in children. Thorax 1998; 53: 117-123.

101. Oryszczyn M-P, Annesi I, Neukirch F, Doré M-F, Kauffmann F. Longitudinal observations of serum $\mathrm{IgE}$ and skin prick test response. Am J Respir Crit Care Med 1995; 151: 663-668.

102. Nielsen NH, Svendsen UG, Madsen F, Dirksen A. Allergen skin test reactivity in an unselected Danish population. Allergy 1994; 49: 86-91.

103. Chan-Yeung MB, Vedal S, Lam S, Enarson D. Immediate skin reactivity and its relation to age, sex, smoking and occupational exposure. Arch Env Health 1985; 40: 53-57.

104. Plaschke P, Janson C, Norman E, et al. Skin prick tests and specific IgE in adults from three different areas of Sweden. Allergy 1996; 51: 461-472.

105. Kuehr J, Frischer T, Karmaus W, et al. Early childhood risk factors for sensitization at school age. J Allergy Clin Immunol 1992; 90: 358-363.

106. Leung RC, Carlin JB, Burdon JG, Czarny D. Asthma, allergy and atopy in Asian immigrants in Melbourne. Med J Aust 1994; 161: 418-425.

107. Karachaliou F-H, Panagiotopoulou K, Manousakis M, Sinaniotis K, Papageorgiou F. Month of birth, atopic disease, and sensitization to common aeroallergens in Greece. Pediatr Allergy Immunol 1995; 6: 216-219.

108. Von Mutius E, Martinez FD, Fritzsch C, Nicolai T, Roell G, Thiemann HH. Prevalence of asthma and atopy in two areas of west and east Germany. Am J Respir Crit Care Med 1994; 149: 358-364.

109. Blumenthal $\mathrm{M}$, Blumenthal $\mathrm{M}$, Bousquet $\mathrm{J}$, et al. Evidence for an increase in atopic disease and possible causes. Clin Exp Allergy 1993; 23: 484-492.

110. Weiss ST, Tager IB, Munoz A, Speizer FE. The 
relationship of respiratory infections in early childhood to the occurrence of increased levels of bronchial responsiveness and atopy. Am Rev Respir Dis 1985; 131: 573-578.

111. O'Connor GT, Sparrow D, Segal MR, Weiss ST. Smoking, atopy and methacholine airway responsiveness among middle-aged and elderly men. Am Rev Respir Dis 1989; 140: 1520-1526.

112. Venables KM, Dally MB, Nunn AJ, et al. Smoking and occupational allergy in workers in a platinum refinery. BMJ 1989; 299: 939-942.

113. Taylor MR, Holland CV, Spencer R, Jackson JF, $\mathrm{O}^{\prime}$ Connor GI, O'Donnell JR. Haematological reference ranges for schoolchildren. Clin Lab Haematol 1997; 19: 1-15.

114. Nutman TB, Ottesen E, Cohen SG. Eosinophilia and eosinophil-related disorders. In: Middleton E Jr, Reed C, Ellis EF, Adkinson NF Jr, Yunginger JW, eds. Allergy, Principles and Practice. St Louis, Washington, 1988; pp. 861-887.

115. Bain B, Seed M, Gosland I. Normal values for peripheral blood white cell counts in women of four different ethnic origins. J Clin Pathol 1984; 37: 188193.

116. Ulrik CS. Peripheral eosinophil counts as a marker of disease activity in intrinsic and extrinsic asthma. Clin Exp Allergy 1995; 25: 820-827.

117. Nduka N, Aneke C, Maxwell-Owhochuku S. Comparison of some haematological indices of africans and Caucasians resident in the same Nigerian environment. Haematologia 1988; 21: 57-63.

118. Schwartz J, Weiss ST. Cigarette smoking and peripheral blood leucocyte differentials. Ann Epidemiol 1994; 4: 236-242.

119. Tollerud DJ, Weiss ST, Brown LM, Malonev EM, Blattner ?. Racial differences in serum IgE level and eosinophil count in healthy smokers and non smokers. Am Rev Respir Dis 1992; 145: A538.

120. El-Nawawy A, Soliman AT, El-Azzouni O, El-Sayed A, Demian S, El-Sayed M. Effect of passive smoking on frequency of respiratory illnesses and serum immunoglobulin-E (IgE) and interleukine-4 (IL-4) concentrations in exposed children. $J$ Trop Pediatr 1996; 42: 166-169.

121. Jensen EJ, Pedersen B, Narvestadt E, Dahl R. Blood eosinophil and monocyte counts are related to smoking and lung function. Respir Med 1998; 92: 63-69.

122. Sunyer J, Munoz A, Peng Y, et al. Longitudinal relation between smoking and white blood cells. Am J Epidemiol 1996; 144: 734-741.

123. Wieslander $G$, Norbäck D, Björnsson E, Janson C, Boman G. Asthma and the indoor environment: the significance of emission of formaldehyde and volatile organic compounds from newly painted indoor surfaces. Int Arch Occup Environment Health 1997; 69: 115-124.

124. Baldacci S, Viegi G, Paoletti P, et al. Skin prick tests reactivity to common airborne allergens and associated conditions in a general population sample of North Italy. Eur Respir J 1993; 6: 624s.

125. Stein RT, Holberg CJ, Morgan WJ, et al. Peak flow variability, methacholine responsiveness and atopy as markers for detecting different wheezing phenotypes in childhood. Thorax 1997; 52: 946-952.

126. Droste JH, Kerhof M, de Monchy JG, Schouten JP, Rijcken B. Association of skin test reactivity, specific IgE, total IgE, and eosinophils with nasal symptoms in a community-based population study. The Dutch ECRHS Group. J Allergy Clin Immunol 1996; 97: 922-932.

127. Pereira Vega A, Sanchez Ramos JL, Maldonado Perez JA, Ayerbe Garcia R, Gomez Entrena M, Gravalos Guzman J. Relation between asthma and atopy markers in children and young adults. Arch Broncopneumol 1997; 33: 272-277.

128. Calbi M, Giacchetti L, Coppola A, Triggiani M. Basophil count in neonates is not suitable for atopy predictivity. J Investig Allergol Clin Immunol 1996; 6: 383-387.

129. Sluiter HJ, Koëter GH, de Monchy JGR, Postma DS, de Vries K, Orie NGM. The Dutch Hypothesis (chronic non-specific lung disease) revisited. Eur Respir J 1991; 4: 479-489.

130. Peat JK, Toelle BG, Dermand J, van den Berg R, Britton WJ, Woolcock AJ. Serum IgE levels, atopy, and asthma in young adults: results from a longitudinal cohort study. Allergy 1996; 51: 804-810.

131. Kauffmann F, Dizzier M-H, Pin I, et al. Epidemiological study of the genetics and environment of asthma, bronchial hyperresponsiveness, and atopy. Am J Respir Crit Care Med 1997; 156: S123-S129.

132. Wiesch D, Meyers D, Samet J, Bleecker E. Classification of the asthma phenotype in genetic studies. In: Liggett S, Meyers D, eds. The genetics of asthma. New York, Marcel Dekker, 1996; pp. 421-442.

133. Burrows B, Knudson R, Cline M, Lebowitz M. A reexamination of risk factors for ventilatory impairment. Am Rev Respir Dis 1988; 138: 829-836.

134. Parker D, O'Connor G, Sparrow D, Segal M, Weiss S. The relationship of nonspecific airway responsiveness and atopy to the rate of decline of lung function. $\mathrm{Am}$ Rev Respir Dis 1990; 141: 589-594.

135. Annesi I, Oryszczyn M, Frette C, Neukirch F, OrvoenFrija E, Kauffmann F. Total circulating IgE and FEV1 in adult men. An epidemiological longitudinal study. Chest 1992; 101: 642-648.

136. Dow L, Coggon D, Campell M, Osmond C, Holgate S. The interaction between immunoglobulin $\mathrm{E}$ and smoking in airflow obstruction in the elderly. Am Rev Respir Dis 1992; 146: 402-407.

137. Omenaas E, Bakke P, Eide G, Elsayed S, Gulsvik A. Total serum IgE and FEV1 by respiratory symptoms and obstructive lung disease in adults of a Norwegian community. Clin Exp Allergy 1995; 25: 682-689.

138. Tracey M, Villar A, Dow L, Coggon D, Lampe F, Holgate S. The influence of increased bronchial responsiveness, atopy, and serum IgE on decline in FEV1. Am J Respir Crit Care Med 1995; 151: 656-662.

139. Chan-Yeung M, Abboud R, Dy Buncio A, Vedal S. Peripheral leucocyte count and longitudinal decline in lung function. Thorax 1988; 43: 462-466.

140. Dow L. Desperately seeking a solution - total serum immunoglobulin E and airways obstruction. Clin Exp Allergy 1995; 25: 673-677.

141. Annesi I, Oryszczyn M, Neukirch F, Orvoen-Frija E, Korobaeff M, Kauffmann F. Relationship of upper airways disorders to FEV1 and bronchial hyperresponsiveness in an epidemiological study. Eur Respir $J$ 1992; 5: 1104-1110.

142. Sherrill D, Sears M, Lebowitz M, et al. The effects of airway hyperresponsiveness, wheezing, and atopy on longitudinal pulmonary function in children: a 6-year follow-up study. Pediatr Pulmonol 1992; 13: 78-85.

143. Omenaas E, Bakke P, Eide G, Elsayed S, Gulsvik A. 
Serum house dust mite antibodies: predictor of increased bronchial responsiveness in adults of a community. Eur Respir J 1996; 9: 919-925.

144. Björnsson E, Norbäck D, Janson C, et al. Asthmatic symptoms and indoor levels of micro-organisms and house dust mites. Clin Exp Allergy 1995; 25: 423-431.

145. Harving H, Korsgaard J, Dahl R. Clinical efficacy of reduction in house-dust mite exposure in specially designed, mechanically ventilated healthy homes. Allergy 1994; 49: 866-870.

146. European Community Respiratory Health Survey (ECRHS) - Italy. Determinants of bronchial responsiveness in the European Community Respiratory Health Survey in Italy: evidence of an independent role of atopy, total serum IgE levels, and asthma symptoms. Allergy 1998; 53: 673-681.

147. Chinn S, on behalf of the European Community Respiratory Health Survey. Individual allergens as risk factors for bronchial responsiveness in the European Community Respiratory Health Survey (ECRHS). Eur Respir J 1998; 12: Suppl. 28, 358s.

148. Sunyer J, Antó J, Sabrià J, et al. Relationship between serum IgE and airway responsivenss in adults with asthma. J Allergy Clin Immunol 1995; 95: 699-705.

149. Burrows B, Sears M, Flannery E, Herbison G,
Holdaway M, Silva P. Relation of the course of bronchial responsiveness from age 9 to age 15 to allergy. Am J Respir Crit Care Med 1995; 152: 1302-1308.

150. Pattemore P, Holgate S. Bronchial hyperresponsiveness and its relationship to asthma in childhood. Clin Exp Allergy 1993; 23: 886-890.

151. Peat J, Tovey E, Mellis C, Leeder S, Woolcock A. Importance of house dsut mite and Alternaria allergens in childhood ashma: an epidemiological study in two climatic regions of Australia. Clin Exp Allergy 1993; 23: 812-820.

152. Hargreave F, Ryan G, Thomson N, et al. Bronchial responsiveness to histamine or methacholine in asthma: measurement and clinical significance. $J$ Allergy Clin Immunol 1981; 68: 347-355.

153. Ferrante E, Corbo G, Valente S, Ciappi G. Associations between atopy, asthma history, respiratory function and non-specific bronchial responsiveness in unselected young asthmatics. Respiration 1992; 59: 169-172.

154. Takeda K, Shibasaki M, Takita H. Relation between bronchial responsiveness to methacholine and levels of $\mathrm{IgE}$ antibody against Dermatophagoides farinae and serum $\operatorname{IgE}$ in asthmatic children. Clin Exp Allergy 1993; 23: 450-454. 